\title{
Sovereignty, Substance, and Public Support for European Courts' Human Rights Rulings
}

\author{
MIKAEL RASK MADSEN University of Copenhagen, Denmark \\ JUAN A. MAYORAL University of Copenhagen, Denmark, and Carlos III University of \\ Madrid, Spain \\ ANTON STREZHNEV University of Chicago, United States \\ ERIK VOETEN Georgetown University, United States, and University of Oslo, Norway
}

\begin{abstract}
I $s$ the public backlash against human rights rulings from European courts driven by substantive concerns over case outcomes, procedural concerns over sovereignty, or combinations thereof? We conducted preregistered survey experiments in Denmark, France, Poland, Spain, and the United Kingdom using three vignettes: a foreigner who faces extradition, a person fighting a fine for burning Qurans, and a home owner contesting eviction. Each vignette varies with respect to whether a European court disagrees with a national court (deference treatment) and whether an applicant wins a case (outcome treatment). We find little evidence that deference moves willingness to implement judgments or acceptance of court authority but ample evidence that case outcomes matter. Even nationalists and authoritarians are unmoved by European court decisions as long as they agree with the case outcome. These findings imply that nationalist opposition to European courts is more about content than the location of authority and that backlash to domestic and international courts may be driven by similar forces.
\end{abstract}

\section{INTRODUCTION}

$\mathbf{T}$ The European Court of Human Rights (ECtHR) and the Court of Justice of the European Union (CJEU) have come under intense public scrutiny over some of their human rights rulings. First, critics charge that European courts have interfered on issues that should be decided by domestic institutions. This is a procedural argument about the proper location for authority. Second, critics have condemned European courts on substantive grounds - for example, because courts protect the rights of immigrants who have been convicted of a crime. Although these critiques can be complementary, they are conceptually distinct and they have different implications. However, the rapidly growing literature on backlash against international institutions has not yet disentangled the extent to which people object to international authority on procedural or substantive grounds.

\footnotetext{
Mikael Rask Madsen (ID, Professor, iCourts, Faculty of Law, University of Copenhagen, Denmark, mikael.madsen@jur.ku.dk.

Juan A. Mayoral (D), Ramón y Cajal Research Fellow, Department of Social Sciences, Carlos III University of Madrid, Spain, and Global Research Fellow, iCourts, Faculty of Law, University of Copenhagen, Denmark, juan.mayoral@uc3m.es.

Anton Strezhnev $(\mathbb{D}$, Assistant Professor, Department of Political Science, University of Chicago, United States, astrezhnev@uchicago.edu. Erik Voeten (iD, Peter F. Krogh Professor of Geopolitics and Justice in World Affairs, Edmund A. Walsh School and Department of Government, Georgetown University, United States, and Visiting Professor, PluriCourts, University of Oslo, Norway, ev42@georgetown.edu.
}

Received: August 05, 2020; revised: February 26, 2021; accepted: September 07, 2021. First published online: November 5, 2021.
We conducted preregistered survey experiments in Denmark, France, Poland, Spain, and the United Kingdom to disentangle these motivations in the context of human rights jurisprudence. ${ }^{1}$ We used three case vignettes in which an individual contests a government action: a foreign criminal who faces expulsion, a person fighting a fine for burning the Quran, and a home owner contesting eviction. Each vignette had two treatment conditions: whether a European court rules differently from a national court (deference treatment) and whether an applicant wins or loses (outcome treatment). We evaluated whether the treatment affects agreement with the decision, support for compliance, and support for European Court authority. Moreover, we examined whether individuals who strongly identify as exclusive nationalists respond differently to disagreement between European and national courts.

We find substantial outcome treatment effects. However, with the partial exception of Denmark and the United Kingdom, we find no significant procedural sovereignty effects. Most respondents appear to be just fine with a European court disagreeing with a national court as long as they get the outcomes they like. This is equally, and sometimes more, true for those who are generally skeptical of European institutions, such as individuals with exclusive nationalist and authoritarian leanings. These findings are consistent with the idea that the correlation between exclusive national identity and support for European institutions runs through the effect these institutions are perceived to have on immigration and other policies that ethnocultural nationalists

\footnotetext{
${ }^{1}$ An anonymized version of the pre-registration is submitted with the manuscript. EGAP, registration ID 20191220AA.
} 
dislike rather than an innate preference for national over European institutions.

These findings shed light on two theoretical debates. First, scholars have long contested whether the subjective legitimacy of (international) institutions, including courts, is driven by satisfaction with outcomes or procedural fairness (Caldeira and Gibson 1995; Dellmuth and Tallberg 2015; Dellmuth, Scholte, and Tallberg 2019; Esaiasson et al. 2019; Follesdal 2020; Gibson and Caldeira 1998; Tallberg and Zürn 2019; Tyler and Rasinski 1991). Most empirical studies focus on procedural features such as transparency, impartiality, or representativeness. Instead, we examine a procedural principle that features prominently in multilevel governance: subsidiarity. Subsidiarity prescribes that the most proximate competent institution should decide controversial issues. However, we find that support for compliance and court authority are unaffected by a European court overruling a national court even among respondents in consolidated democracies and among those who are satisfied with their national legal systems.

To the best of our knowledge, we are the first to examine this question for international institutions. The closest is a study that experimentally manipulates the institutional design of a global climate conference (Anderson, Bernauer, and Kachi 2019). Other experimental studies of backlash against courts focus on framing effects (Dinas and Gonzalez-Ocantos 2021; Gonzalez-Ocantos and Dinas 2019; Zvobgo 2019; Zvobgo and Chaudoin 2021). In addition, there is an experimental literature that finds that policy preferences motivate support for international agreements more than concerns about consistency and reciprocity (Beiser-McGrath and Bernauer 2019; Chaudoin 2014).

A second contribution is to the literature on the nationalist and authoritarian backlash against globalization and international institutions (Ballard-Rosa et al. 2021; Colantone and Stanig 2018; 2019; Copelovitch and Pevehouse 2019; de Vries 2018; Hobolt 2016; Jensen, Quinn, and Weymouth 2017; Mutz 2018). Our findings help disentangle the sources of nationalist opposition to international institutions. International relations scholars often use the term "sovereignty costs" to denote both the procedural and policy losses of delegating authority to international human rights institutions (Hafner-Burton, Mansfield, and Pevehouse 2015; Moravcsik 2000). Public opinion scholars also often conflate the two. For example, Pippa Norris and Ronald Inglehart recognize nationalism, mistrust in global governance, opposition to immigration, and authoritarian values as separate variables that together define the cultural values that are associated with support for populist right-wing parties and opposition to globalization (Norris and Inglehart 2019).

Consistent with the literature, we examine how an exclusive national identity affects support for European institutions (Hooghe and Marks 2004; 2005). If an exclusive nationalist identification is rooted in an affection for a territorial political unit, then we would expect that nationalists object to international court involvement. Yet, if exclusive nationalism is more about an identification with ethnicity and/or cultural values, then we expect that nationalists willingly support the authority of a European court that limits the rights of immigrants or otherwise reaffirms cultural values, even if that means overruling a national court. Our evidence is consistent with the view that nationalist opposition to European human rights adjudication is more about the content of decisions than the location of authority. Nationalists (and authoritarians) oppose implementation of both national and international human rights judgments that they dislike.

The implications of our study are limited by the specific substantive context of our vignettes. We chose our vignettes to mimic the kinds of human rights cases that tap into conflicts over social and moral values. This is justifiable in a study of public backlash. If we are interested in examining whether nationalist opposition to European institutions is driven by an innate preference for national over European institutions or outcomes that ethnocultural nationalists dislike, then we must examine issues that trigger ethnocultural identity. We did find similar patterns on the eviction vignette, which taps into long-standing allegations of the CJEU's neoliberal bias. Yet, our findings may well differ if we had focused on (non-human-rights) regulatory issues or other issues where people have weaker predispositions.

A second limitation is that our vignettes jurisdictionally resemble the ECtHR rather than the CJEU. Our vignettes set up a potential conflict between an international and a national court. In the ECtHR, applicants must first exhaust domestic remedies before bringing their cases. This means that a violation finding by the ECtHR always implies a disagreement with a national court. CJEU rulings do not directly agree or disagree with national courts. Some CJEU judgments on fundamental rights do in practice go against legal interpretations suggested by the referring courts or preexisting national legal practice. For example, the CJEU's Junqueras judgment (on the parliamentary immunity of a pro-Catalan independence politician convicted for sedition) was widely criticized in Spain for ruling in direct contradiction with the Spanish Supreme Court's interpretation of EU law and resulted in a drop in public support for the European Union (Turnbull-Dugarte and Devine 2021). Although we draw inspiration from controversies surrounding CJEU fundamental rights cases, the vignettes themselves are modeled on the ECtHR.

We first offer background for debates about public support for European courts. We then derive testable hypotheses from theoretical frameworks before introducing the research design and data. After presenting the results, the conclusion returns to the institutional implications of our findings and possible extensions to other institutional settings.

\section{BACKGROUND}

European integration has become politicized to the extent that a transnational cleavage now permeates most European political systems (Hooghe and Marks 2009; 2018). This cleavage divides parties and citizens on immigration, national identity, European integration, and the distribution of benefits from globalization. This 
politicization includes European courts. Especially, human rights litigation has become controversial as domestic and international courts increasingly resolve high-salience disputes, including cases about identity, immigration, and economic redistribution (e.g., Helfer 2018; Hirschl 2008; Sandholtz, Bei, and Caldwell 2017).

The ECtHR offers direct access for individuals in all 47 Council of Europe (CoE) member states. The Court issued only 200 judgments between 1960 and 1990 but well over 20,000 judgments since. All CoE member states have incorporated the European Convention on Human Rights into domestic law. As explained above, ECtHR violation findings imply a disagreement between a national and an international court over whether a government action violated human rights.

The CJEU examines a more diverse set of cases, mostly concerning the single market and economic freedoms. Its human rights jurisdiction expanded with the adoption of the Charter of Fundamental rights in the 2009 Lisbon Treaty (Craig and De Búrca 2020). The CJEU hears most of its human rights cases through its preliminary references procedure. ${ }^{2}$ A national court must refer a question of EU law to the CJEU if there is doubt about its interpretation (Broberg and Fenger 2014). While the CJEU never directly overrules national courts, the preliminary reference procedure creates situations in which conflicts between the CJEU interpretation and prevailing national judicial practice or preferred legal interpretations is apparent and controversial, as in the aforementioned Junqueras judgment. Such controversies should ultimately be resolved in favor of EU law due to the long-standing principle of the supremacy of EU law. Yet, some national apex courts have carved out exceptions to the autonomy and supremacy of EU law for fundamental rights (Gill-Pedro 2019; Mohay and Tóth 2017). Thus, both the location of authority and the content of fundamental rights judgments are subject to contestation in the CJEU context.

Politicians and other critics have increasingly accused the ECtHR of overstepping its authority (Flogaitis, Zwart, and Fraser 2013; Hofmann 2018; Madsen, Cebulak, and Wiebusch 2018; Popelier, Lambrecht, and Lemmens 2016; Stiansen and Voeten 2020). The CJEU has long been criticized for its alleged neoliberal bias - that it prioritizes the free movement of goods, services, labor, and capital over competing objectives, such as social policies and protections (Höpner and Schäfer 2012; Pollack 2017; Scharpf 1998). More recently, right-wing parties have adopted nationalist and authoritarian rhetoric to criticize human rights rulings on both European courts (Madsen 2020). This includes mainstream parties and government officials. For example, Theresa May stated repeatedly that the UK should leave the ECtHR (and not the EU), famously illustrating her pleas with the example of a case of an "illegal immigrant who cannot be deported because, and I am not making this up, ${ }^{3}$ he had a pet

\footnotetext{
${ }^{2}$ As opposed to infringement cases filed by the Commission.

${ }^{3}$ There is no evidence that Maya the cat was decisive in the matter: https://www.bbc.com/news/uk-politics-15171980.
}

cat." The UK Conservative Party (the governing party) promised in its 2015 manifesto to "curtail the role of the [ECtHR] so that foreign criminals can be more easily deported from Britain." 4

Similarly, the Spanish populist party Vox stated in its 2019 manifesto that "The institutions of the Union and especially the Court of Justice of the Communities have abused their competences" and proposes a new treaty to curb the court. ${ }^{5}$ Vox's parliamentary spokesman called the Junqueras decision: "a stick to Spain, an attack on national sovereignty," ${ }^{, 6}$ and the party threatened a Spaxit after the ruling. ${ }^{7}$ In Madrid, street protests erupted over an ECtHR ruling that reduced the effective prison sentences of convicted ETA terrorists. ${ }^{8}$

Governments have adopted a series of multilateral declarations from the Brighton Declaration (2012) to the Copenhagen Declaration (2018) that have urged the ECtHR to apply greater restraint in its jurisprudence (Helfer 2018). There is evidence that the Court has responded to especially the concerns from governments in consolidated democracies (Stiansen and Voeten 2020). Similarly, some scholars suggest that the CJEU has started to exercise more restraint in policy areas where both the public and member state governments are opposed to further legal integration, such as citizenship law (Blauberger and Martinsen 2020). Moreover, CJEU judgments are increasingly (and negatively) reported in the media (Blauberger et al. 2018; Dederke 2021).

That European courts receive increased scrutiny does not necessarily mean that people dislike the principle of European Court authority. It may be that some vocal groups are dissatisfied with the the outcomes of particular rulings, whereas they would appreciate European courts setting aside national court rulings on other matters. Our article examines this question.

\section{THEORY AND HYPOTHESES}

\section{Procedural Justice, Subsidiarity, and Deference}

Procedural justice theories posit that people are willing to accept unpopular court decisions as long as these are made through a process that they perceive as fair (e.g., Tyler 2006; Tyler and Rasinski 1991). Procedural fairness reflects values that are unrelated to the outcome of

\footnotetext{
${ }^{4}$ The Conservative Party Manifesto (2015), 58. https://www. theresavilliers.co.uk/sites/www.theresavilliers.co.uk/files/

conservativemanifesto2015.pdf.

5 https://www.voxespana.es/wp-content/uploads/2019/05/ProgramaEuropeas-2019_web.pdf, p.5.

${ }^{6}$ https://www.libertaddigital.com/espana/politica/2019-12-19/voxarremete-contra-la-sentencia-sobre-puigdemont-y-junqueras-es-unpalo-a-espana-un-ataque-a-la-soberania-nacional-1276649702/.

7 "Spain's Vox party under pressure to back 'Spaxit' after EU court ruling." https://www.telegraph.co.uk/news/2019/12/21/spains-voxparty-pressure-back-spaxit-eu-court-ruling/.

${ }^{8}$ See "The Assassin Walks Free." The Economist, October 26, 2013. https:/www.economist.com/europe/2013/10/26/the-assassin-walksfree.
} 
cases, such as impartiality, transparency, and honesty (Tyler 2006, 7).

We examine procedural concerns about the location of authority. We first scrutinize the idea that people, on average, inherently value proximate national-level decision making, for example because they have an attachment to the nation state or because they feel more involved with or trusting of national-level decisions regardless of the outcome of these decisions. The assumption is often implicit in the statements of politicians. For example, Kenneth Clarke, Lord Chancellor and Secretary of State for Justice, said in the 2011 Izmir ECtHR reform conference that

If the Strasbourg Court is too ready to substitute its own judgment for that of national parliaments and courts that have through their own processes complied with the Convention, it risks turning the tide of public opinion against the concept of international standards of human rights, and risks turning public opinion against the Convention itself.

Individual-level preferences for national over equivalent international institutions need not be unconditional. This idea is reflected in the subsidiarity principle, which prescribes that an international institution should only have authority when it can perform a task better and when more decentralized (national) units cannot reach decisions on their own (Follesdal 1998). This principle presumes a preference for national institutions, all things equal. The subsidiarity principle is written into the Treaty of the European Union-Article 5(3) of the Treaty on European Union (TEU) and Protocol (No 2)-and was added to the preamble of the European Convention on Human Rights through Protocol No. 15 (2013). ${ }^{9}$ The ECtHR's newly elected President, judge Robert Spano, has argued that the court has entered an "age of subsidiarity" (Spano 2014), claiming that "in this process-based mechanism, the Court may grant deference if national decision-makers are structurally capable of fulfilling that task" (Spano 2018, 493). The 2018 Copenhagen Declaration mentions subsidiarity six times and states that the ECtHR should "[..]not substitute its own assessment for that of the domestic courts, unless there are strong reasons for doing so." 10

The assumption that people value subsidiarity also underlies many international relations theories. For example, Andrew Moravcsik argues that international human rights courts help democratizing states' make their commitment to implement rights reforms more credible. By contrast, democracies with independent and effective domestic courts have no reason to accept intrusions by international courts (Moravcsik 2000). The implicit underlying behavioral theory is that backlash results from the unwillingness of people in developed democracies to accept the sovereignty cost of international courts overruling competent national courts.

\footnotetext{
${ }^{9}$ The Protocol has yet to take effect.

10 https://www.echr.coe.int/Documents/Copenhagen_Declaration_ ENG.pdf.
}

Despite the centrality of the subsidiarity principle in European integration and in international relations theory, there is little research that explicitly examines its behavioral implications. We test two hypotheses. The first, baseline, deference hypothesis is that people are less willing to implement and support decisions reached through an international court disagreeing with a national court either because they inherently value proximate (national) authority or because they live in an established democracy where national courts are working well.

H1a (Deference): Support is lower if the European court disagrees with the national court.

The subsidiarity argument implies that H1a may be less pronounced in Poland than in the more consolidated democracies. But the subsidiary rationale could also operate at the individual level, which implies a heterogeneous treatment effect. Are respondents who look upon their domestic institution more favorably more affected by a European institution disagreeing with a national institution? This question has been studied for political institutions, although not experimentally. For example, Rohrschneider (2002) finds that citizens who perceive that their national democratic institutions are performing well have lower levels of EU regime support and are less likely to support reforms toward an EU-level government. We examine this in an experimental context for legal institutions.

H1b (Subsidiarity): The more satisfied an individual is with the domestic legal system the more support decreases if the European court disagrees with the national court.

Thus, whereas H1a tests whether individuals inherently prefer decisions that come from national courts, $\mathrm{H} 1 \mathrm{~b}$ examines whether support depends on individual assessments of whether national courts are competent.

\section{Substantive Legitimacy}

Substantive legitimacy theories posit that publics afford international legal institutions at best a minimal store of procedural legitimacy that would help controversial decisions gain acceptance (Caldeira and Gibson 1995; Gibson and Caldeira 1998). Because people know very little about how these courts make decisions, trust tends to be derivative of trust in international institutions more broadly and of general legal values. However, this trust is not sufficiently specific to induce people to accept unfavorable judgments (Caldeira and Gibson 1995; Gibson and Caldeira 1998). This theory implies that people may be perfectly fine with international courts overruling competent national courts as long as they agree with the outcome. Indeed, outcome favorability may color perceptions of procedural fairness (Esaiasson et al. 2019), thus increasing support not just for the implementation of the decision but also the authority of the court.

Politicians frequently resort to outcome-based criticisms. For example, British Prime Minister David 
Cameron argued in a parliamentary debate over the implementation of the ECtHR Hirst ruling on prisoners' voting rights that: "it makes me physically ill to even contemplate having to give the vote to anyone in prison" (Hough 2011). Yet, European court judgments are not necessarily unpopular. For example, some of the CJEU's opinions on privacy rights, such as Google $v$. Spain that established a "right to be forgotten," appear quite popular: ${ }^{11} 75 \%$ of Europeans support the right to delete personal information from any website. ${ }^{12}$

The substantive legitimacy thesis implies that European courts could increase or decrease support by disregarding national courts, depending on whether the public on average sympathizes with an applicant.

H2a (Outcome effect): Support is lower if an unsympathetic applicant wins or a sympathetic applicant loses a case.

$\mathrm{H} 2 \mathrm{a}$ raises the obvious issue of heterogeneity in preexisting beliefs. Clearly individuals who are more sympathetic to immigrants should be more sympathetic to a Court that protects immigrant rights than individuals who are less favorably disposed toward immigrants' human rights.

H2b (Outcome heterogeneity: sympathy): Individuals who value the applicant's rights unfavorably are less likely to support a court (ruling) supporting the applicant.

\section{Nationalism}

Scholars have long found that people who exclusively conceive of their identity in national rather than European terms are more likely to oppose European integration (Clark and Rohrschneider 2019; Fligstein, Polyakova, and Sandholtz 2012; Hooghe and Marks 2004; 2005; McLaren 2005). Although national and European identities may reinforce each other, EU skeptics have increasingly framed the debate as being about the defense of the nation against control from Brussels, Luxembourg, and Strasbourg. Liesbeth Hooghe and Gary Marks find evidence for their hypothesis that "citizens who see themselves as exclusively national are particularly receptive to elite warnings that European integration harbors unacceptable foreign influence" (Hooghe and Marks 2005, 426). Others have shown that people with exclusively nationalist identities are less likely to favor international cooperation (Herrmann, Isernia, and Segatti 2009) and much more likely to support radical right-wing parties (Dunn 2015), and parties that use exclusive nationalist rhetoric in their manifestos also strongly contest international authority (Ecker-Ehrhardt 2014).

While the correlation between exclusive national identity and support for European institutions is well

\footnotetext{
11 Judgment of the Court (Grand Chamber), May 13, 2014. Google Spain SL and Google Inc. v. Agencia Española de Protección de Datos (AEPD) and Mario Costeja González.

12 https://ec.europa.eu/public_opinion/archives/ebs/ebs_359_en.pdf.
}

established, the precise nature of this relationship remains somewhat unclear (Hobolt and de Vries 2016). Among the open questions is whether defining national identity in exclusive terms implies an objection to the principle of locating authority away from the nation or whether it is about the substance of European integration. The theoretical expectations depend on whether nationalists identify their attachment to the nation in civic terms or ethnic and cultural terms.

A civic conception is that nationalism is a group identity defined by an affective connection with the political territorial unit in which people reside (e.g., Wright, Citrin, and Wand 2012). The in-group consists of fellow nationals regardless of ethnicity or cultural demarcations. In this understanding, "unacceptable foreign influence" would include a European court that sets aside a national court judgment. Thus, following this logic, we would expect that those who have an exclusive national identity will react more negatively to a European court overruling a national court.

H3a (Procedural heterogeneity: nationalism): Perceived sovereignty costs increase the more nationalist an individual is.

Exclusive nationalism can, however, also be understood as a demarcation of cultural in-groups and outgroups, or nativism, which has been a defining feature of many European right-wing populist parties (Bar-On 2018; Mudde 2004). An ethnic or cultural conceptualization of nationalism follows from beliefs about the nature of the nation rather than just its territorial borders (Dunn 2015). In this conception, the link between nationalism and European integration runs through substantive issues that are perceived as challenges to traditional conceptions of the nation rather than foreign interference per se. For example, selfdefined national identity correlates strongly with fear of especially Islamic immigration (Sides and Citrin 2007). Moreover, attitudes about immigration correlate strongly with preferences over European integration, as the EU is perceived to encourage immigration (de Vreese and Boomgaarden 2005; Hobolt 2016). A nativist might support European institutions that protect them from non-European immigration, as suggested by the "fortress Europe" language that some right-wing parties have adopted (Lamour and Varga 2020). This more cultural conception of nationalism implies that exclusive nationalists should be moved primarily by the outcome treatment, especially on the vignettes referencing immigration and Islam.

H3b (Outcome heterogeneity: nationalism): Nationalists are more likely to support court rulings against someone outside of the cultural or ethnic in-group regardless of whether the ruling comes from an international court.

\section{Authoritarianism}

Like nationalism, authoritarian values have been strongly associated with opposition to globalization 
TABLE 1. Distribution of Vignettes

\begin{tabular}{lllll}
\hline UK & Denmark & Spain & France & Poland \\
\hline Deportation & Deportation & Deportation & Deportation & Deportation \\
Quran burning & Quran burning & Eviction & Eviction & LGBT Rights
\end{tabular}

and international institutions (Ballard-Rosa et al. 2021; Norris and Inglehart 2019). Interest in authoritarian values dates back to the 1950s when scholars sought to understand the personality traits of individuals who supported the Nazis and other fascist movements (Adorno et al. 1993). Authoritarians place great value on conformity with in-group norms and desire uniformity. Authoritarians have punitive and intolerant attitudes toward threats that may fragment society and often favor aggressive, even violent, suppressions of those threats.

There are different ways to conceptualize and measure authoritarianism. One approach is to assess personality traits by asking respondents about appropriate ways to teach and discipline children at home (Dunn 2015; Feldman and Stenner 1997; Stenner 2005). An alternative, adopted in this article, is to assess right-wing authoritarianism more directly as a combination of aggression, submission, and conventionalism (Altemeyer 1988; Dunwoody and Funke 2016). The literature has already found a robust correlation between these measures and opposition to immigration, Islam, ethnocentrism, political intolerance, and antidemocratic attitudes (Altemeyer 1988; Ballard-Rosa et al. 2021; Dunwoody and Funke 2016; Dunwoody and McFarland 2018).

In accordance with this literature, we hypothesize that people with strong authoritarian values are more likely to be moved by the outcome treatment, especially on the immigration and Quran-burning vignettes of our study. Indeed, authoritarians may be skeptical of the very idea of human rights litigation. Because authoritarianism is also associated with respect for traditional authority, which is located at the national level, we also examine whether people with strong authoritarian values are less accepting of a European court contradicting a national court.

H4a (Procedural heterogeneity: right-wing authoritarianism): Perceived sovereignty costs increase the more authoritarian an individual's values are.

H4b (Outcome heterogeneity: right-wing authoritarianism): Support for a court (ruling) will vary depending on how authoritarian an individual's values are.

\section{RESEARCH DESIGN}

We designed survey experiments that disentangle responses to information about a European court disagreeing with a national court and case outcomes. Our research design is similar to an emerging experimental literature that examines whether and to what extent the public punishes democratically elected leaders for process violations, such as sidestepping legislatures through unilateral actions (Becher and Brouard 2019; Christenson and Kriner 2017; Graham and Svolik 2020; Reeves and Rogowski 2018).

Qualtrics conducted the survey in Denmark, France, Poland, Spain, and the United Kingdom to a sample of around 3,000 respondents per country. The five countries were chosen to assess the generalizability of our findings rather than to examine cross-country hypotheses. These five countries represent variation across both the North-South and East-West axes of Europe. Poland is the only newer democracy and a country that is widely perceived to be backsliding. In all countries, right-wing authoritarian and nationalist movements are relevant and have challenged international court judgments. We used one vignette in all countries for half of the sample and administered three different vignettes to the other half (see Table 1). This approach balances concerns about our findings' dependence on country and vignette context while ensuring that our main vignette has sufficient power.

Unfortunately, a translation error prevents us from interpreting the data on the LGBT rights vignette (on pride parades) in a coherent way. Appendix C contains more details.

\section{Deportation Vignette}

The deportation vignette is (UK example):

Suppose that United Kingdom (UK) authorities decided to deport a foreigner who has been convicted of a crime. The foreigner appealed at a UK court that the decision to deport him violated his human rights. The UK court found that the authorities [CAN/CANNOT] deport the foreigner. The question was then brought before a European court, which [AGREED WITH/DISAGREED WITH] the UK court. The final decision is that the foreigner should [REMAIN IN THE UK/BE DEPORTED].

We chose this stylized case as our main example because the issue is politically salient in all countries and both national and European courts have produced numerous judgments on similar issues. Our interest is not in estimating the effect of a "typical case" but in whether controversial judgments are more acceptable if they come from a national rather than a European court.

In only this vignette, we include a control condition that eliminates the sentence on the European Court. This assesses the possibility that the mere mention of a European court raises sovereignty concerns. This creates the following six assignment categories (see Table 2). 
TABLE 2. Categorization of Treatment Conditions in Deportation Vignette

\begin{tabular}{|l|c|c|c|}
\hline & $\begin{array}{c}\text { European Court agrees with } \\
\text { National Court }\end{array}$ & $\begin{array}{c}\text { European Court disagrees with } \\
\text { National Court }\end{array}$ & $\begin{array}{c}\text { National court only } \\
\text { decision maker }\end{array}$ \\
\hline $\begin{array}{l}\text { Applicant } \\
\text { wins }\end{array}$ & 1 & 3 & 5 \\
\hline $\begin{array}{c}\text { Applicant } \\
\text { loses }\end{array}$ & 2 & 4 & 6 \\
\hline
\end{tabular}

In scenario 1, the applicant wins in the national court and the European court agrees. In scenario 3, the applicant loses in the national court but wins in the European court. In scenario 5, the applicant wins in national court and there is no European court ruling. Scenarios 2, 4, and 6 mirror these, but now the applicant loses. The outcome effect is the contrast between conditions 1, 3, and 5 (blue cells) with 2, 4, and 6 (yellow cells). The sovereignty effect is the contrast between 3 and 4 and 1 and 2. We use 5 and 6 as a placebo test to examine whether the mere mention of European court involvement matters. Previous studies have found that setting appropriate benchmarks may matter for evaluating procedural justice perceptions (Werner and Marien 2020).

The exercise is abstract but not unrealistic. We refer to a "European court" and remain deliberately vague about whether this concerns the ECtHR or the CJEU, as we do not presume that respondents know the difference. We abstract away from jurisdictional issues. The ECtHR can only directly hear cases in boxes 2 and 3 , where the applicant initially loses in the national court. ${ }^{13}$ The CJEU mostly weighs in on deportation cases through its preliminary references procedure and does not formally agree or disagree with national courts but provides the authoritative interpretation of EU law. Yet, politicians and media often frame the role of European courts in ways that reflect all boxes.

For example, in 2016 the Danish Supreme Court ruled that expelling a non-Danish citizen with an extensive and public criminal record, would constitute a violation of the European Convention. The Danish Court argued that: "[..] despite the severity of his current crime and despite his criminal career, [the request] for deportation would be a disproportionate infringement on his rights in respect to his private and family life."14 This decision caused uproar among Danish politicians and helped instigate efforts to reform the ECtHR (Madsen 2020). The ECtHR had not actually ruled counter to the national court (as in scenario 1), yet the press portrayed the situation as though it was a scenario 3 case where the Danish commitment to the Court led to the inability to expel

\footnotetext{
${ }^{13}$ Unless the government does not implement the national court decision in scenario 1 .

14 http://domstol.fe1.tangora.com/New-S\% C3\% B8geside.31488. aspx? recordid31488=1222.
}

the person. Another case, involving a different member of the same family with a long criminal $\mathrm{CV}$, did reach the ECtHR. In this case, the ECtHR found that the Danish court had given "relevant and sufficient reasons" to expel him (scenario 2). ${ }^{15}$

Jurisdictionally, the most difficult scenario is the 4th, in which the applicant wins a domestic case but the European court disagrees. Governments do not have the right to appeal national court decisions for alleged violations of European law. Yet, it is entirely possible that a European court is more sympathetic to the government's concerns than a national court would have been.

An example is a German case involving a Turkish national of Kurdish origin (Mr. T).$^{16} \mathrm{Mr}$. T was recognized as a refugee and granted an indefinite resident permit in Germany in 1993 based on his political activities in support of the PKK (Lampert 2017). After he was convicted of supporting a terrorist organization, the Karlsruhe regional government determined in 2009 that Mr. T qualified as a "present danger" and that he should be expelled and that his residency permit should be evoked. The High Administrative Court accepted Mr. T's appeal in 2012. The Court expressed doubt about the revocation of Mr. T's residency permit, temporarily restored that permit, and requested a preliminary ruling from the CJEU. Yet, in 2015, the CJEU found that a residence permit to a refugee may be revoked where there are "compelling reasons of national security or public order," including participation in a terrorist organization. ${ }^{17}$ The CJEU judgment gave an interpretation that was less favorable to the applicant than the preliminary national court decision.

There are other, similar, examples especially on migration and citizenship law. For example, the CJEU, contrary to the opinion of the national referring court, declared that the notion of "freedom to provide services" in the Additional Protocol to the TurkeyEU Association Agreement must be interpreted as not encompassing freedom for Turkish nationals who are the recipients of services to visit a Member State, thus denying Turkish citizens EU access without a

\footnotetext{
${ }^{15}$ CASE of Levakovic v. Denmark (Application no. 7841/14), October 23, 2018.

${ }^{16}$ H. T. v. Land Baden-Württemberg, C-373/13, European Union: Court of Justice of the European Union, June 24, 2015.

${ }^{17}$ H. T. v. Land Baden-Württemberg, C-373/13, European Union: Court of Justice of the European Union, June 24, 2015.
} 
visa (Hatzopoulos 2014). Danish courts have arguably applied a security margin (sikkerhedsmargin) in some expulsion cases fueled by a desire to not be overruled by the ECtHR, making protection standards higher than in ECtHR case law (Madsen 2018). The 4th scenario is theoretically and substantively interesting even if jurisdictionally unrealistic.

\section{Quran-Burning Vignette}

In the second vignette, we chose an applicant that should be relatively more sympathetic to supporters of right-wing authoritarian parties. The vignette is modeled on a series of cases that balance free speech with other rights. For example, in E.S v. Austria, the ECtHR upheld a domestic court's fine for an Austrian woman who had called the prophet Mohammed a pedophile. The European court was widely criticized for this judgment by right-wing politicians and columnists (Smet 2019), suggesting that the authoritarian right wanted the European court to overrule the national court.

Our vignette is the following (using DK example):

Suppose that the Danish authorities have fined an individual who burned the [QURAN] for disturbing public order and inciting hatred. The individual appealed that the decision violated her rights to freedom of speech at a Danish court. The Danish court found that the authorities [CAN/CANNOT] impose the fine. The question was then brought before a European court, which [AGREED WITH/DISAGREED WITH] the Danish court. The final decision is that the Danish authorities [CAN IMPOSE THE FINE/CANNOT IMPOSE THE FINE].

\section{Eviction Vignette}

The vignettes above appeal to cases that are controversial due to identity issues. Yet, economic issues are also an important driving force behind dissatisfaction with globalization, including in the European court context (e.g., Höpner and Schäfer 2012). Major corporations or banks have prevailed, but individuals have also won major cases against Google, Facebook, or against state laws that were seen as insufficiently protective. In these instances, the applicant may be more appealing to the political left.

We based our vignette roughly on Mohamed Aziz v. Catalunyacaixa, a CJEU case that ruled that the Spanish civil code and civil proceedings law violates EU law because it does not give applicants the right to file lawsuits on the basis that the terms of the initial loan include provisions that are unfair. ${ }^{18}$ While Aziz was eventually evicted, the case changed the procedural challenges that mortgage holders can raise before eviction. The human rights dimension of this case derives from article 47 of the EU Charter of Fundamental Rights that provides fair trial rights to all rights arising

${ }^{18}$ Case C-415/11, March 14, 2013. from EU law, in this case Council Directive 93/13/EEC on unfair terms in consumer contracts. The CJEU thus ruled that the Spanish legal system made it impossible for mortgage holders to enforce their consumer rights against major banks. ${ }^{19}$ The ECtHR also has an extensive case law on eviction, sometimes concluding that individuals were wrongly evicted. ${ }^{20}$ Fundamentally, this is a case about an individual's right to be protected by the state from potentially predatory practices by banks. Both national and European courts play an important role in guaranteeing these rights. We construct the following vignette (using the Spanish example):

Suppose that Spanish authorities, at the request of a bank, requested the eviction of an individual who had not paid his mortgage. The individual appealed the decision, charging that the terms and conditions of the bank's loan were unfair and violated his rights. A Spanish court found that the authorities [CAN/CANNOT] evict the individual from his home until a decision is made on the legality of the contract. The question was then brought before a European court, which [AGREED WITH/DISAGREED WITH] the Spanish court. The final decision is that the Spanish authorities [CAN/CANNOT] evict the individual.

\section{DATA AND METHOD}

\section{Survey}

Each survey targeted 3,000 respondents recruited from each country via Qualtrics Panels from January 27 to February 27 of 2020 . This service is an online opt-in survey platform. All respondents were informed that they were taking part in a research study and were given the names and contact information of the principal investigators. All respondents were asked for their consent. No identifying information was presented to the investigators, nor was any deception used.

We used quota sampling to ensure that the marginal distributions of important covariates (age, gender, and education) in our sample match known census benchmarks for each country. The census shares, the implied sample quotas, the actual recruitment in each quota group, and the full questionnaire are in the methodological appendix.

\section{Outcome Questions}

We have three outcome measures. First, we simply ask respondents whether they "agree or disagree with the final decision?" Second, we ask respondents whether they "agree that the final decision should be

\footnotetext{
${ }^{19}$ European Union, European Union Agency for Fundamental Rights, and European Union, Council of Europe, Handbook on European law relating to access to justice. Publications Office of the European Union, 2016.

${ }^{20}$ E.g., Connors v. the United Kingdom (66746/01); Winterstein and Others v. France (27013/07).
} 
implemented?" Third, we ask whether they agree their country "should continue to accept the authority of European courts?" All questions were rated on a sixpoint scale from "strongly agree" to "strongly disagree." As preregistered, we present results on dichotomized versions of the outcome variables, but appendix D includes analyses on the continuous measures.

\section{Treatment Effect Moderator Questions}

We preregistered hypotheses about heterogeneous treatment effects. To examine hypothesis $1 b$, we asked respondents "In general terms, how satisfied are you with the way the rule of law works in [country]."

The questions to examine hypothesis $2 \mathrm{~b}$ vary by vignette. For deportation, we used a question that forced respondents to choose whether they think it is worse to give legal status to immigrants who misrepresented their situation back home (e.g., face a death threat back home) or deny legal status to immigrants who did not misrepresent their situation. Similarly, for eviction, we asked whether it was worse to evict people who were treated unfairly by a landlord or mortgage company or to not evict people who have not paid their rent or mortgage. For the Quran-burning vignette we asked respondents whether they agree that the "public display of Islamic symbols such as burkas, veils, and minarets, should be reduced."

Our primary measure for exclusionary nationalism is a common one in the literature: whether people identify themselves as only "British" (using UK example) or also partially or fully as "European" (e.g., Hooghe and Marks 2004). As a robustness check, we also use an additive nationalism scale that in addition to the item above includes the questions: "How proud are you of being British?" In the United Kingdom, our people are not perfect, but our culture is superior to others" and "I would rather be a citizen of the United Kingdom than of any other country in the world."

Authoritarianism is measured by an additive scale based on the Aggression-Submission-Conventionalism (ASC) scale (Ballard-Rosa et al. 2021; Dunwoody and Funke 2016). This scale is based on Altemeyer's research on right-wing authoritarianism, but it avoids items that border on the tautological for outcomes of interest. For example, the Altemeyer scale asks whether "It is important to protect the rights of radicals and deviants in all ways" as well as preferences about homosexuality and civil rights. For the same reason, we exclude the submission component of the ASC scale. Instead, we use the four items that are most strongly associated with the aggression and conventionalism parts of the scale (two of which are reverse coded, marked by *):

A. Police should avoid using violence against suspects.*

B. It is necessary to use force against people who are a threat to authority.

C. Traditions are the foundation of a healthy society and should be respected.

D. People should challenge social traditions in order to advance society.*

\section{Summary Statistics}

Table 3 offers descriptive statistics by vignette and country. There is little cross-country variation in agreement with the decision or implementation. However, as expected, respondents in the UK were much less inclined to accept the authority of European courts. Respondents in the UK and Denmark were on average more likely to be satisfied with domestic courts and more likely to be nationalist: $63 \%$ of UK respondents chose exclusively their national identity compared with just $20 \%$ of Spanish respondents.

We coded respondents who were above 0.5 on the authoritarianism scale (about half of respondents in each country) as "authoritarians." But we also estimated models for the continuous scales for both nationalism and authoritarianism. Authoritarianism and nationalism are only moderately correlated ( 0.34 in the full sample). The authoritarianism scale is lacking in terms of internal reliability. ${ }^{21}$ Yet, the scales do have validity, for example in predicting support for extremeright-wing parties. In Denmark respondents who intend to vote for the Danish People's Party (Dansk Folkeparti) and the New Right (Nye Borgerlige) are much more likely to be authoritarian $(72 \%$ and $78 \%)$ and nationalist (65\% and $64 \%)$ than voters for any other party. In France this holds for respondents who intend to vote for the Rassemblement National (previously known as the National Front), in Spain for Vox voters, and in Poland for Law and Justice (Prawo I Sprawiedliwość) and the Confederation Liberty and Independence (Konfederacja Wolność i Niepodlegtość). In the UK, those who intended to vote for UKIP, the Brexit Party, or the British National Party were all about equally nationalist and authoritarian, although they are not statistically distinguishable from Conservative party voters.

Overall, the sample is somewhat more Eurosceptic than the most recent Eurobarometer (October 2019). That survey found that $24 \%$ of Brits thought EU membership a "bad thing" compared with $28 \%$ in our sample. This difference was higher in France (19\% vs. $11 \%)$, and Denmark (15\% vs. $6 \%$ ). Poland and Spain were below $10 \%$ in both samples.

\section{Estimation}

We estimate the average effect of each treatment, marginalized over the other treatment condition, using a standard poststratified difference-in-means estimator (and in the case of interaction effects, a difference-in-difference-in-means estimator). We estimated the effect within strata constructed using a set of preregistered pretreatment covariates. Poststratification provides a reasonable alternative to stratified randomization to improve the precision of our estimators (Miratrix, Sekhon, and Yu 2013). The covariates that we use to construct the strata are age, gender, level of education, and survey country, and the

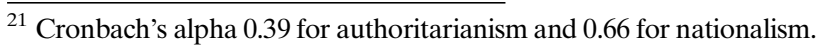


TABLE 3. Summary Statistics (Mean and Standard Deviation)

\begin{tabular}{|c|c|c|c|c|c|c|}
\hline & Denmark & France & Poland & Spain & UK & Overall \\
\hline & $\begin{array}{c}\text { Deportation } \\
(N=1,507)\end{array}$ & $\begin{array}{r}\text { Deportation } \\
(N=1,512)\end{array}$ & $\begin{array}{c}\text { Deportation } \\
(N=1,515)\end{array}$ & $\begin{array}{c}\text { Deportation } \\
(N=1,525)\end{array}$ & $\begin{array}{l}\text { Deportation } \\
(N=1,510)\end{array}$ & $\begin{array}{l}\text { Deportation } \\
(N=7,569)\end{array}$ \\
\hline Agreement & $0.670(0.470)$ & $0.606(0.489)$ & $0.675(0.468)$ & $0.678(0.467)$ & $0.626(0.484)$ & $0.651(0.477)$ \\
\hline Implementation & $0.826(0.379)$ & $0.749(0.434)$ & $0.773(0.419)$ & $0.788(0.409)$ & $0.819(0.385)$ & $0.791(0.407)$ \\
\hline Authority & $0.687(0.464)$ & $0.582(0.493)$ & $0.706(0.456)$ & $0.787(0.409)$ & $0.494(0.500)$ & $0.651(0.477)$ \\
\hline Satisfaction domestic law & $0.593(0.492)$ & $0.313(0.464)$ & $0.313(0.464)$ & $0.355(0.479)$ & $0.472(0.499)$ & $0.409(0.492)$ \\
\hline Sympathy applicant & $0.381(0.486)$ & $0.419(0.494)$ & $0.365(0.482)$ & $0.306(0.461)$ & $0.352(0.478)$ & $0.364(0.481)$ \\
\hline Nationalist & $0.430(0.495)$ & $0.403(0.491)$ & $0.276(0.447)$ & $0.191(0.393)$ & $0.636(0.481)$ & $0.387(0.487)$ \\
\hline \multirow[t]{3}{*}{ Authoritarianism } & $0.535(0.130)$ & $0.538(0.135)$ & $0.556(0.144)$ & $0.537(0.156)$ & $0.542(0.150)$ & $0.542(0.143)$ \\
\hline & Denmark & France & Spain & UK & \multicolumn{2}{|c|}{ Overall } \\
\hline & $\begin{array}{c}\text { Quran burning } \\
(N=1,496)\end{array}$ & $\begin{array}{c}\text { Eviction } \\
(N=1,500)\end{array}$ & $\begin{array}{c}\text { Eviction } \\
(N=1,525)\end{array}$ & $\begin{array}{c}\text { Quran burning } \\
(N=1,523)\end{array}$ & $\begin{array}{c}\text { Eviction } \\
(N=3,025)\end{array}$ & $\begin{array}{l}\text { Quran burning } \\
(N=3,019)\end{array}$ \\
\hline Agreement & $0.681(0.466)$ & $0.639(0.480)$ & $0.681(0.466)$ & $0.659(0.474)$ & $0.660(0.474)$ & $0.670(0.470)$ \\
\hline Implementation & $0.805(0.396)$ & $0.682(0.466)$ & $0.758(0.428)$ & $0.855(0.352)$ & $0.720(0.449)$ & $0.830(0.375)$ \\
\hline Authority & $0.716(0.451)$ & $0.585(0.493)$ & $0.805(0.396)$ & $0.510(0.500)$ & $0.696(0.460)$ & $0.612(0.487)$ \\
\hline Satisfaction domestic law & $0.620(0.485)$ & $0.293(0.455)$ & $0.353(0.478)$ & $0.465(0.499)$ & $0.323(0.468)$ & $0.542(0.498)$ \\
\hline Sympathy applicant & $0.289(0.453)$ & $0.313(0.464)$ & $0.289(0.453)$ & $0.361(0.480)$ & $0.301(0.459)$ & $0.325(0.469)$ \\
\hline Nationalist & $0.431(0.495)$ & $0.408(0.492)$ & $0.199(0.400)$ & $0.632(0.482)$ & $0.303(0.460)$ & $0.533(0.499)$ \\
\hline Authoritarianism & $0.530(0.132)$ & $0.538(0.139)$ & $0.542(0.164)$ & $0.556(0.147)$ & $0.540(0.152)$ & $0.543(0.141)$ \\
\hline
\end{tabular}




\section{FIGURE 1. Mean Proportion "Agree" with Each Outcome Question and 95\% Confidence Intervals by Treatment}
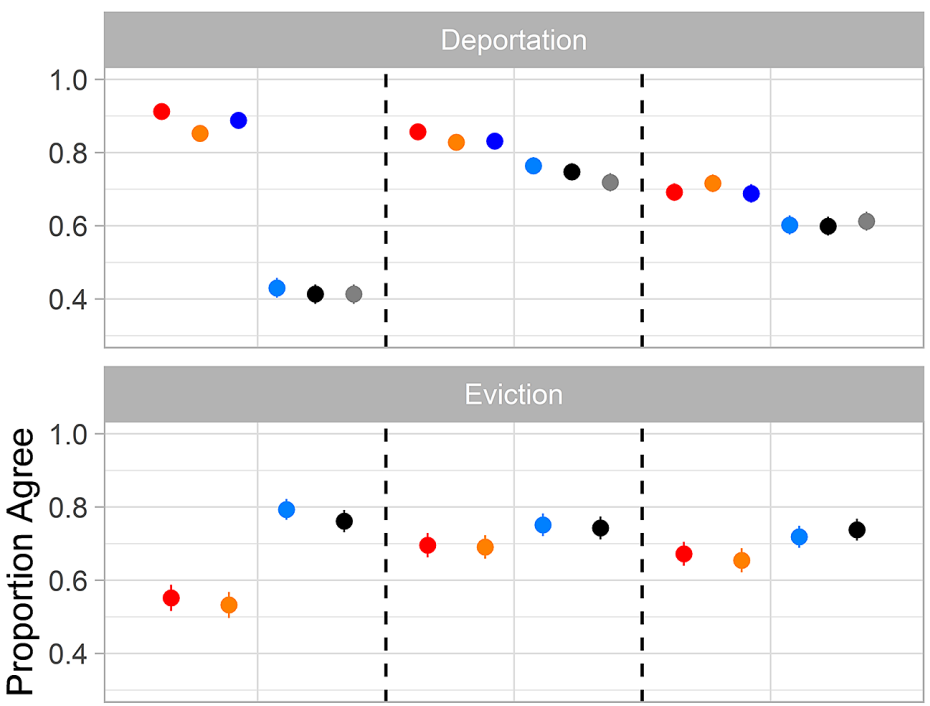

Treatment

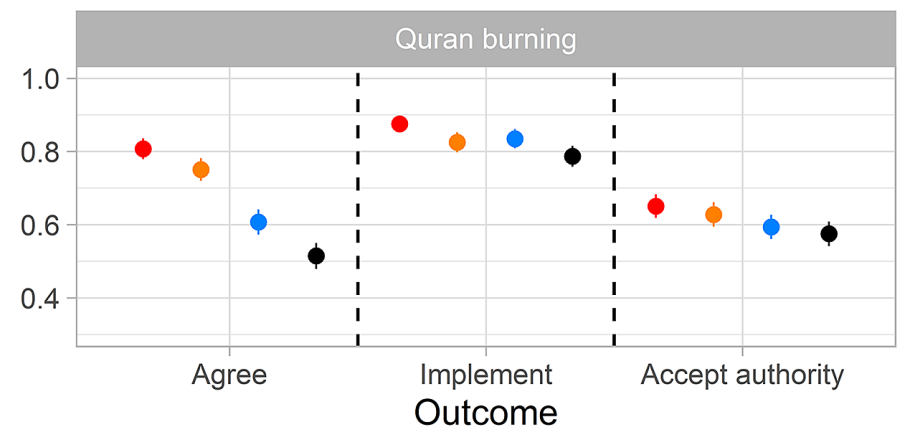

Applicant loses, EC defers (2)

Applicant loses, EC overturns (4)

Applicant loses, No EC (6)

Applicant wins, EC defers (1)

Applicant wins, EC overturns (3)

Applicant wins, No EC (5)

Note: Numbers in parentheses correspond to treatments from Table 2.

specific bins we used are outlined in the methodological appendix. Appendix D produces nonstratified estimates, which yield virtually identical conclusions.

\section{RESULTS}

\section{Summary Effects by Treatment Block}

Figure 1 plots the mean proportion (and the 95\% confidence interval) of respondents who agree on each of the three outcome measures for each of the treatment conditions (denoted by the scenario numbers in Table 2) on each of the three vignettes. This figure is not designed for formal hypothesis tests on treatment effects, but it provides a useful summary of the pattern of responses and allows visual comparisons between mean responses across the treatment conditions.

The treatment effects for agreement with the decision are much larger than for implementation and authority. Respondents clearly differentiate between the outcomes. For example, the figure shows that in a number of the treatment conditions where a large share of the respondents disagree with the decision outcome-such as the applicant winning in the deportation vignette $-\mathrm{a}$ much smaller share endorse nonimplementation. This suggests that there are respondents who, despite disagreeing with the decisions, still support implementing them. If the ultimate test for subjective legitimacy is whether people believe that decisions that they disagree with should nonetheless be implemented (Caldeira and Gibson 1995; Gibson, Caldeira, and Baird 1998), then European courts do have legitimacy.

Overall, there is no evidence that respondents' answers on the placebo treatment that made no mention of the European court are significantly different from the other treatment conditions. To ease presentation, we omit this condition from further tables and figures (see results including the placebo group in appendix D).

\section{Deference (H1)}

Figure 2 plots the average treatment effects of the European court disagreeing versus agreeing with the domestic court (full tables are in Appendix E). While in the deportation vignette we find slight negative effects on respondents' agreement with the decision and 
FIGURE 2. Average Treatment Effect of European Court Disagreeing with a Domestic Court

\section{Effect of EC disagreeing with domestic court}

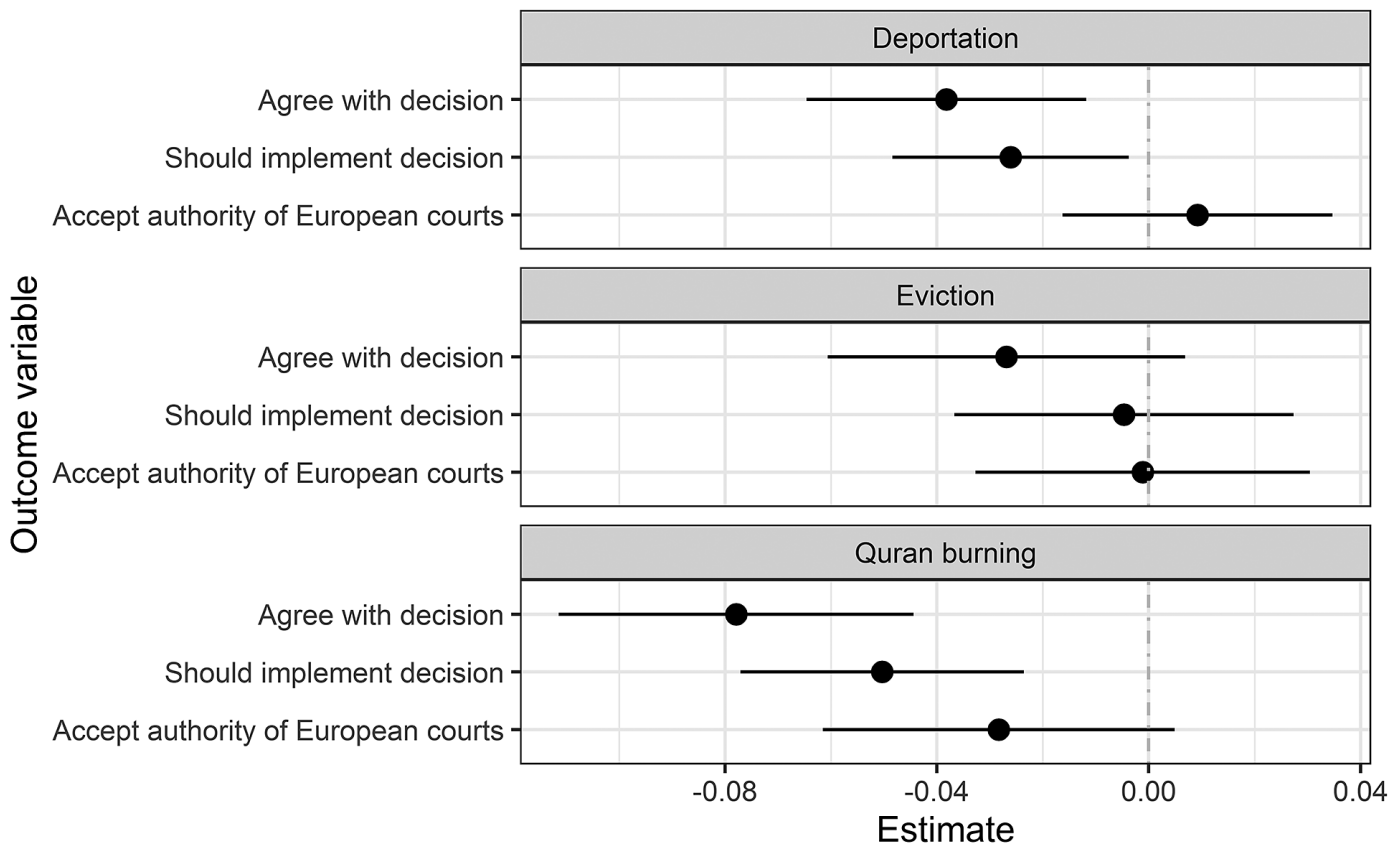

Note: Lines denote $95 \%$ confidence intervals.

beliefs that the decision should be implemented, the magnitude of these effects is relatively small-less than 4 percentage points. The treatment effects are not significantly different from zero for any of the outcomes on the eviction vignette. The estimated effects are somewhat larger for the Quran-burning vignette on both agreement and belief that the decision should be implemented, but in all three vignettes we find no treatment effect on respondent's overall belief that their government should continue to accept the authority of European courts.

On closer inspection, the differences across vignettes could be a function of the countries in which the vignettes were administered. On the deportation vignette, the estimated effect of the deference treatment on implementation was largest in Denmark, Poland, and the UK, although it did not reach conventional levels of statistical significance in any individual country. Averaging over the deportation and Quran vignettes, the no-deference condition reduced support for implementation (but not court authority) among Danish respondents by 5 percentage points $(p=0.001)$ and among British respondents by 3.8 percentage points $(p=0.007)$. Among French and Spanish respondents, the no-deference condition did not reduce support for decisions or implementation in either the deportation or eviction vignettes.

That the British and Danish publics appear more sensitive to European court deference appears consistent with hypothesis $1 \mathrm{~b}$ : that people who are satisfied with the domestic rule of law are also less enthusiastic about international court interference. However,
Figure 3 provides no evidence for an individual-level interaction. In none of the vignettes for none of the outcome measures do people who are satisfied with the domestic rule of law respond differently to a lack of EC court deference than people who are dissatisfied. The absence of an interaction remains if we subset our analysis to the UK and Denmark in particular.

\section{Outcome Effects (H2)}

Figure 4 plots the average treatment effects of the case outcome treatment: the effect of a win for the applicant versus a loss for the applicant. For this treatment, the effects on both agreement and support for implementation and acceptance of European court authority are much larger in magnitude than for the deference treatment. A win for the applicant reduces agreement with the judgment by 46 percentage points in the deportation vignette and by 22 percentage points in the Quran-burning vignette. By contrast, respondents on average found the applicant more sympathetic in the eviction vignette with a win for the applicant raising support by 24 percentage points.

The effects on support for implementation were more modest but still statistically significant: $8.5,5.5$, and 4.2 percentage points on deportation, eviction, and Quran burning, respectively. Moreover, unlike the deference treatment, the outcome treatment also significantly affects support for the authority of the European court (10.4, 6.1, 5.3 percentage points, respectively). That is, the act of defying a national court does not 
FIGURE 3. Interaction between Satisfaction with Domestic Rule of Law and Deference

\section{Effect of EC disagreement,} by satisfaction with domestic rule of law

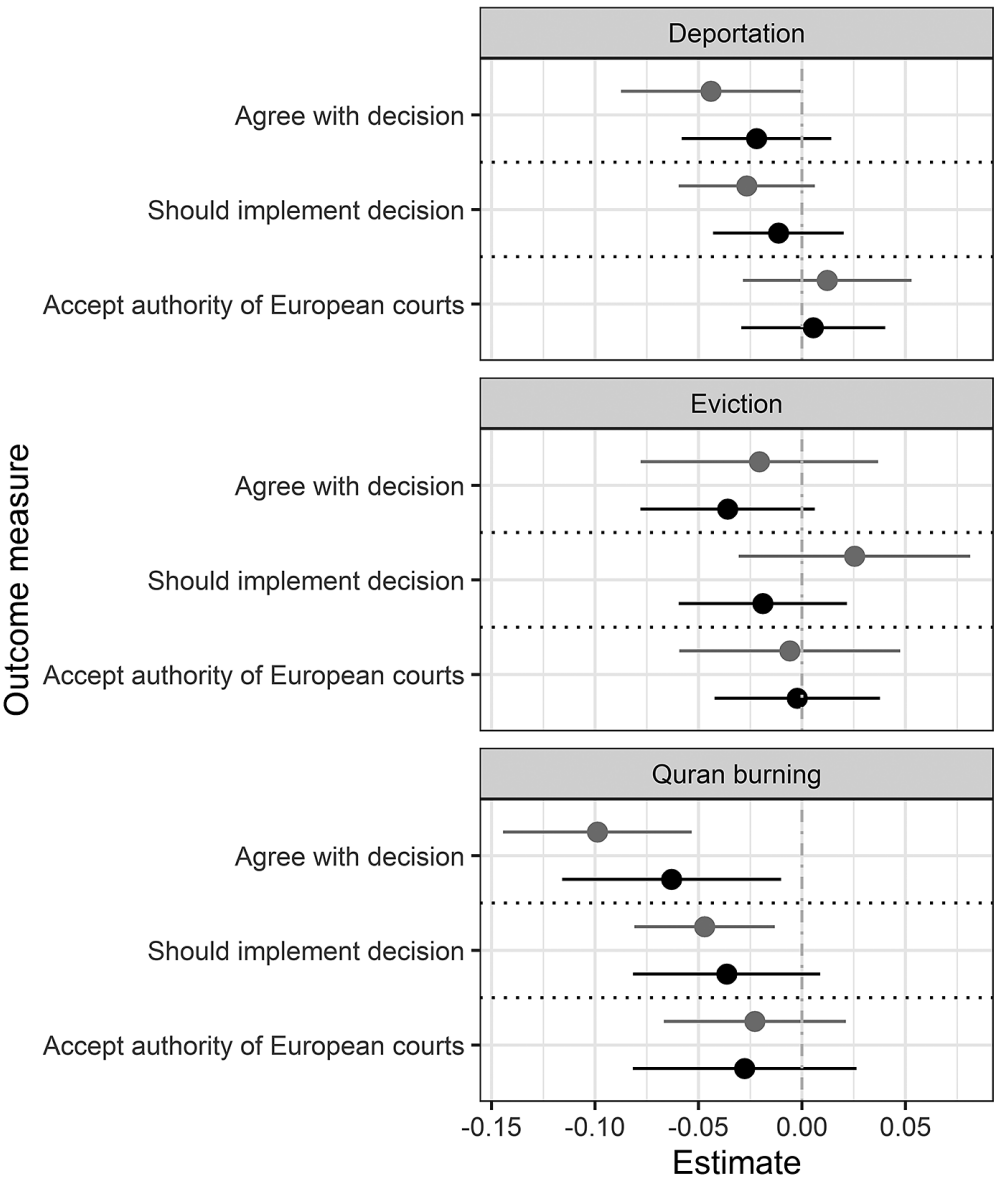

Rule of law satisfaction

reduce support for European court authority but producing an outcome where a disliked applicant wins or, in the case of eviction, a likeable applicant loses, does reduce support for European court authority. Closer inspection finds that these effects are remarkably consistent across countries (see appendix D).

We conducted a series of tests to examine whether the coefficient on the case outcome treatment was larger than the deference treatment. We found that the case outcome treatment effects were significantly larger (at $p=0.01$ ) in all instances other than for the implementation and authority outcomes in the Quran vignette, where we could not reject the null hypothesis of no difference between the coefficients.

Figure 5 examines hypothesis $2 b$, which states that the effect of the outcome treatment should be more negative for individuals who are less sympathetic to an applicant's rights. Recall that our measures are pretreatment and do not capture agreement with the decision but general predispositions toward human rights (e.g., would you rather wrongly deport or wrongly admit an immigrant?).
There are sizeable interaction effects on most measures. For example, in all three vignettes support for implementation is 9-10 percentage points lower among applicants who are predisposed against the applicant if they are assigned to the treatment in which the applicant wins. The effects are largest in the eviction vignette. The treatment effect of an applicant win on accepting the authority of European courts is 13 percentage points larger for respondents who believe it is worse to evict a tenant who has been maltreated than to not evict a tenant who just has not paid the rent (about $70 \%$ of respondents).

\section{Nationalism}

Are respondents who self-identify as exclusive nationalists more responsive to the deference treatment? Consistent with the literature, respondents who selfidentify as only having a national identity are much less likely to agree that their country should continue to accept the authority of European courts regardless of treatment condition. The smallest difference is in Spain 


\section{FIGURE 4. Average Treatment Effect of Case Outcome}

\section{Effect of case outcome}

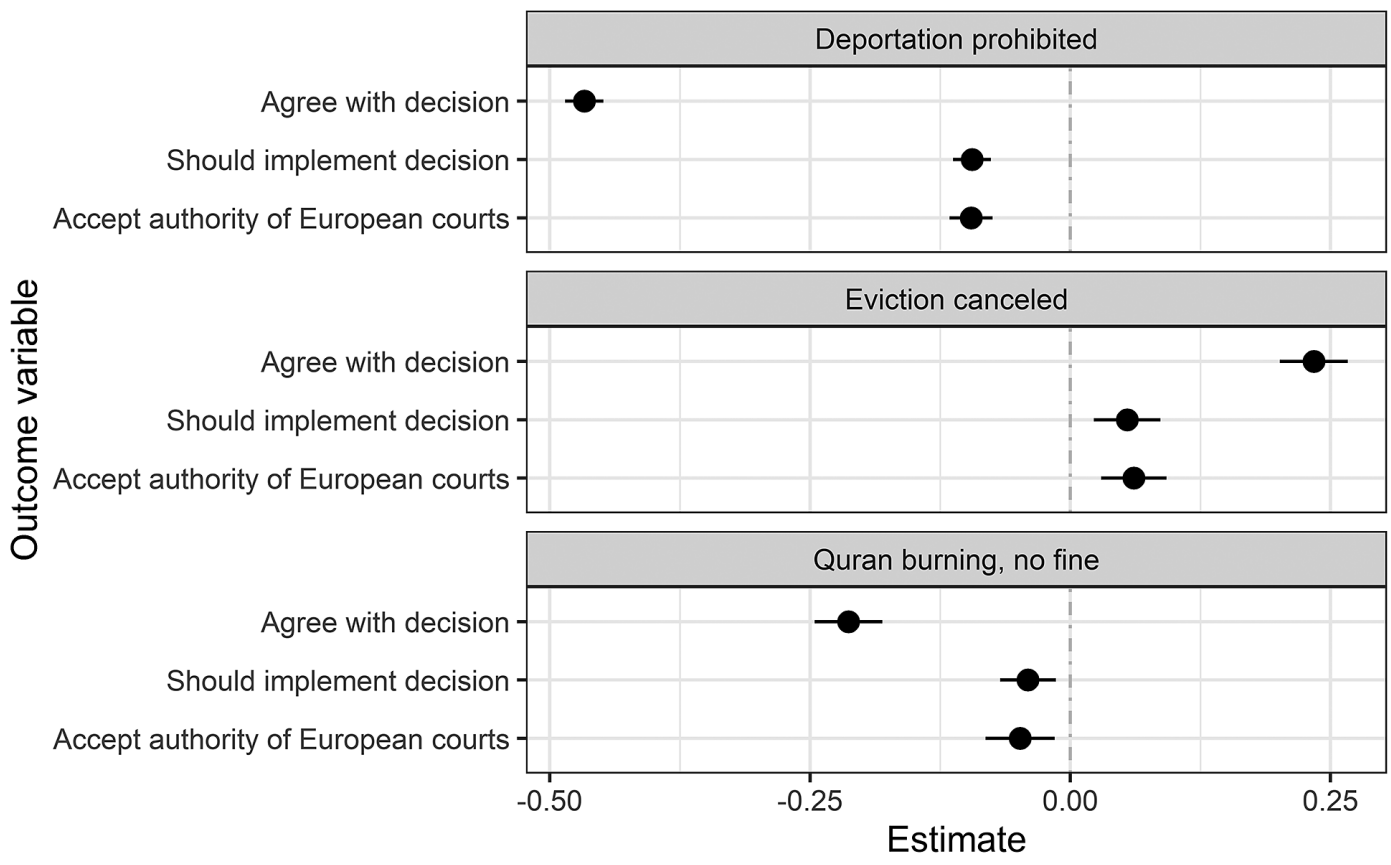

Note: Lines denote $95 \%$ confidence intervals.

( $65 \%$ vs. $83 \%$ ) and the largest in the UK ( $38 \%$ vs. $72 \%)$ and France $(41 \%$ vs. $70 \%)$, although a much larger proportion of the British population identifies as nationalist in the UK than in France (64\% vs. $40 \%$, respectively). ${ }^{22}$

Figure 6 evaluates hypotheses $3 a$ and $3 b$. Overall, there is no evidence that nationalist respondents disagree more with decisions, their implementation, or the authority of European courts when the European court refuses to defer to the national court. If we evaluate countries individually, we do not find evidence that nationalists are significantly more likely than nonnationalists to adjust their agreement with the decision or support for implementation and court authority based on the deference treatment in any of the vignettes.

By contrast, nationalists are much more responsive than nonnationalists to the outcome of the deportation vignette. The treatment effect of an immigrant win on acceptance of court authority and support for implementation is 7.5 percentage points larger for nationalists than nonnationalists, although it is still also significant for nonnationalists. Note that it does not matter whether the decision came about because the European court overturned or upheld the national court, the outcome is the primary driver of response especially for nationalists. Moreover, when we include the condition that makes no

\footnotetext{
${ }^{22} \mathrm{We}$ do not find such differences on support for agreement or implementation without separating respondents by treatment condition.
}

mention of a European court, we find the same effect: nationalists are less likely than are nonnationalists to support implementation of a national court decision when the foreigner avoids deportation.

Nationalists are also relatively more sympathetic than nonnationalists to the applicant in the Quranburning vignette. Nationalists are 10 percentage points more likely to agree with the decision and 9 percentage points more likely than are nonnationalists to favor implementation if the fine gets repealed. There is no significant interaction between nationalism and the treatment effect of the outcome on support for the authority of the court.

Nationalists and nonnationalists do differ slightly in terms of their response to the outcome treatment in the eviction vignette. Interestingly, the effect of the applicant winning in the eviction vignette on agreement is larger for nonnationalists than nationalists (though the effect is positive and statistically significant in both subgroups). However, the effect on support for implementation is slightly larger among nationalists than nonnationalists. This is consistent with a possible "ceiling" effect where nonnationalists may generally be supportive of implementation irrespective of their level of agreement.

We repeated all analyses with the four-item nationalism scale using more flexible interaction models (see appendix D). The findings were consistent with those presented here: no significant interactions for the deference treatment, but we do find significant and substantively important interactions for the outcome treatment. These findings support the idea that the 


\section{FIGURE 5. Interaction between Sympathy toward Applicant Rights and Outcome Treatment}

\section{Effect of Outcome,}

by predispositions towards rights claimant
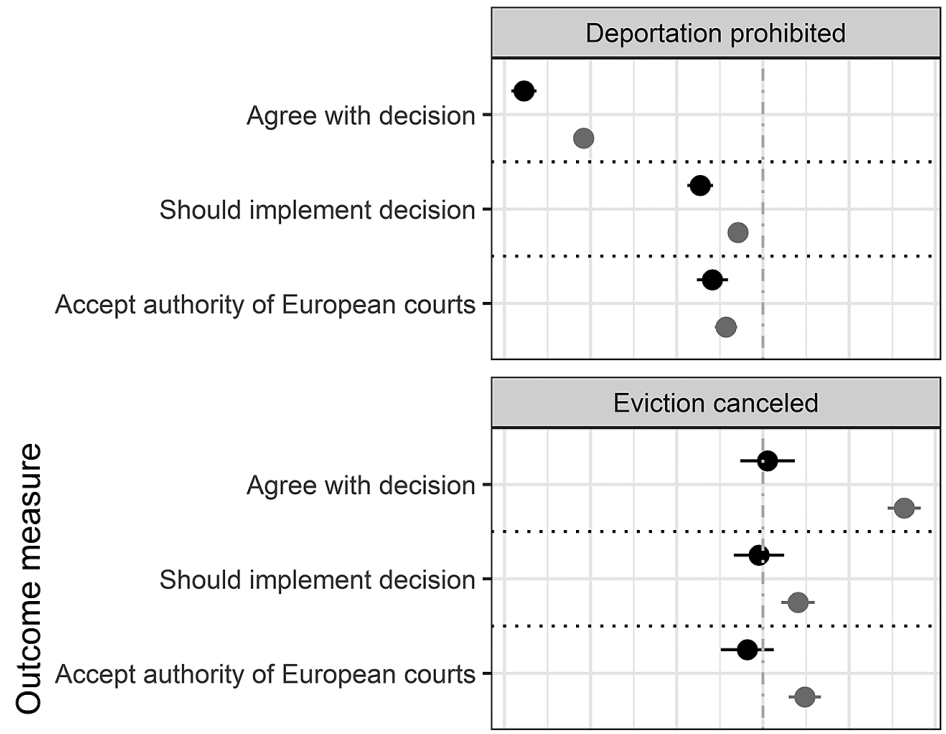

Sympathy towards rights claimant
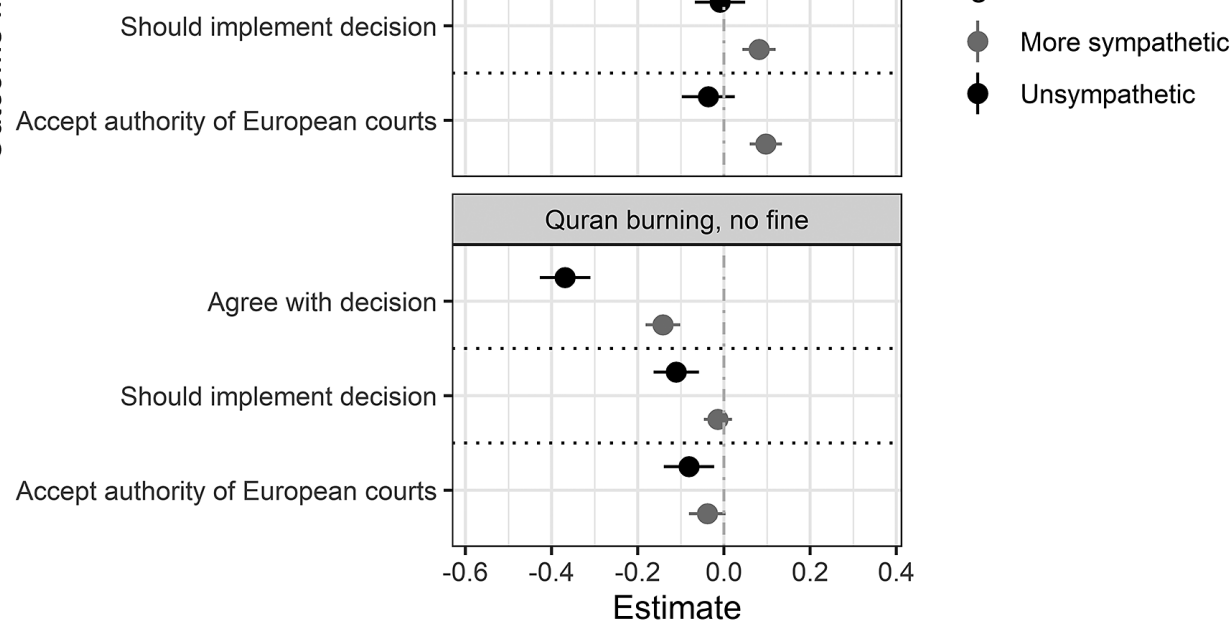

Note: Lines denote $95 \%$ confidence intervals.

correlation between exclusive national identity and support for European institutions runs through the effect European institutions are perceived to have on immigration and other policies that ethnocultural nationalists dislike rather than an innate preference for national over European institutions.

\section{Authoritarianism}

Figure 7 shows the heterogeneity in treatment effect estimates by individuals' authoritarianism. Authoritarians are not more or less moved than nonauthoritarians by a European court sidestepping a national court. Especially on the deportation case, however, the effect of the outcome treatment is much larger for authoritarians on both implementation (11 percentage points) and acceptance of court authority (9 percentage points). Despite professed respect for authority, authoritarians are more likely to support nonimplementation of court decisions they do not like compared with nonauthoritarians.

Perhaps surprisingly, we do not observe as strong an interaction in the Quran-burning case: authoritarians are 5 percentage points more likely than nonauthoritarians to favor implementation when the applicant wins. In the flexible interaction models (appendix), we find that this is primarily driven by people in the top third of the authoritarianism distribution. However, we find no effect on court authority. One possibility is that the applicant in this case is not just anti-Islam but also displays behavior that disrespects public authority. On the eviction vignette, we find that authoritarians respond less positively to the applicant winning a case but the heterogeneous effect is only evident when the outcome is agreement with the decision.

\section{Right-Wing Populism and Euroskepticism}

We also examined (not preregistered, in appendix D) whether respondents who indicated their intent to vote for right-wing populist parties ${ }^{23}$ respond differently to

\footnotetext{
${ }^{23}$ We use the PopuList to identify right-wing populist parties (Rooduijn et al. 2019).
} 
FIGURE 6. Nationalism and Treatment Effects

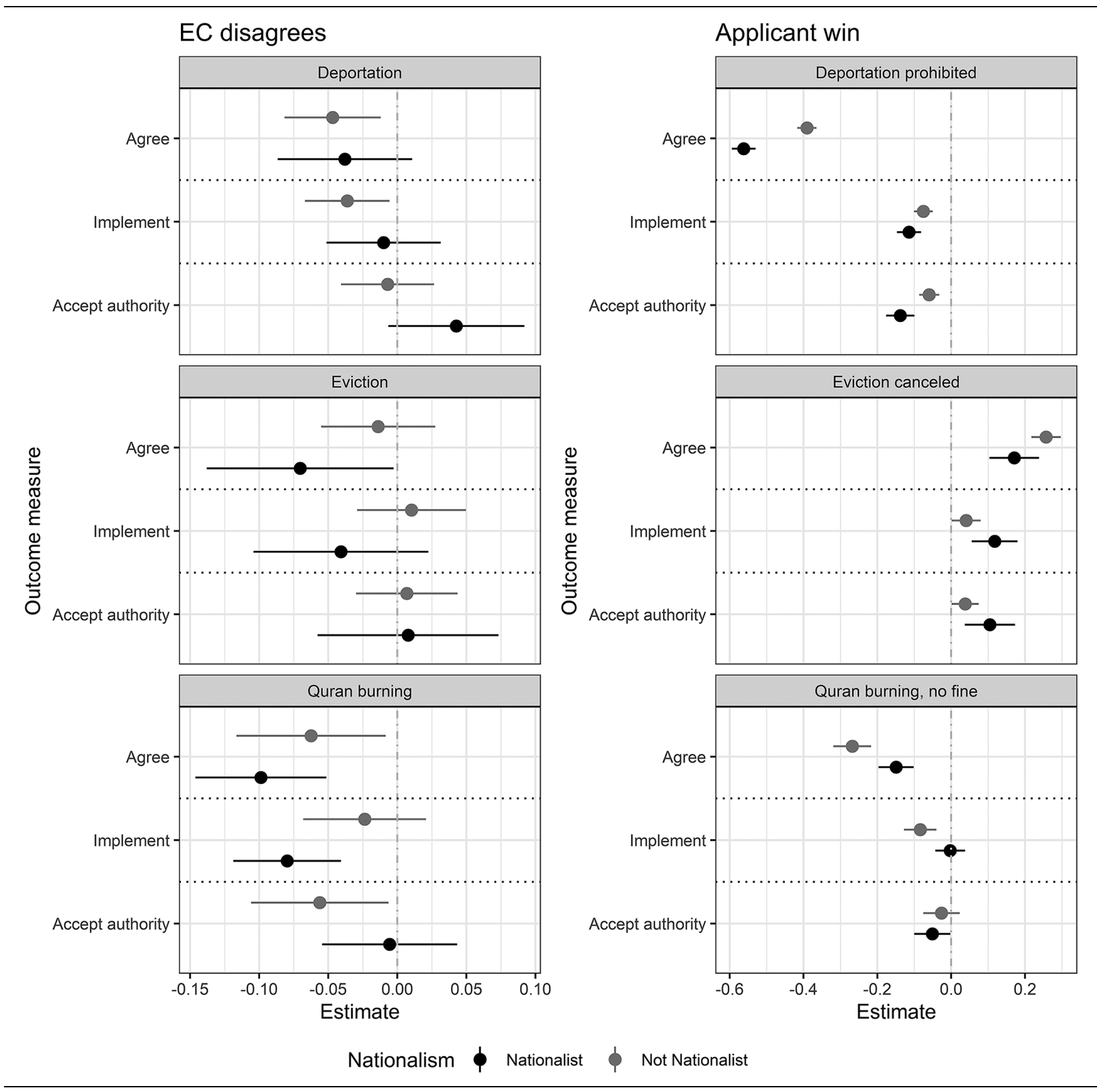

Note: Lines denote $95 \%$ confidence intervals.

the treatments. The results are very similar to those on authoritarianism and nationalism: large heterogeneous effects on the outcome treatment for the deportation vignette and to a lesser extent the Quran-burning vignette. However, we found no differences on the deference treatment.

Similarly, those respondents who said that EU membership was either "bad" or "very bad" (asked pretreatment) are also unresponsive to the European court disregarding the national court, but they are highly responsive to the outcome treatments. Eurosceptics are 10 percentage points less likely than non-Eurosceptics to favor compliance following the immigrant winning and 10 percentage points more likely to support implementation if the person who burns Qurans and the home owner fighting eviction win. The effects on support for European court authority are not significant, but this could be because baseline support among Eurosceptics is so low to begin with: just 26\% agree that European courts should have authority.

In short, our evidence implies that neither respondents with nationalist or authoritarian values nor those who indicate a vote preference for right-wing populist parties or those who think that EU membership is bad for their countries respond to a lack of deference by a European court, but they are responsive to outcomes. 
FIGURE 7. Authoritarianism and Treatment Effects

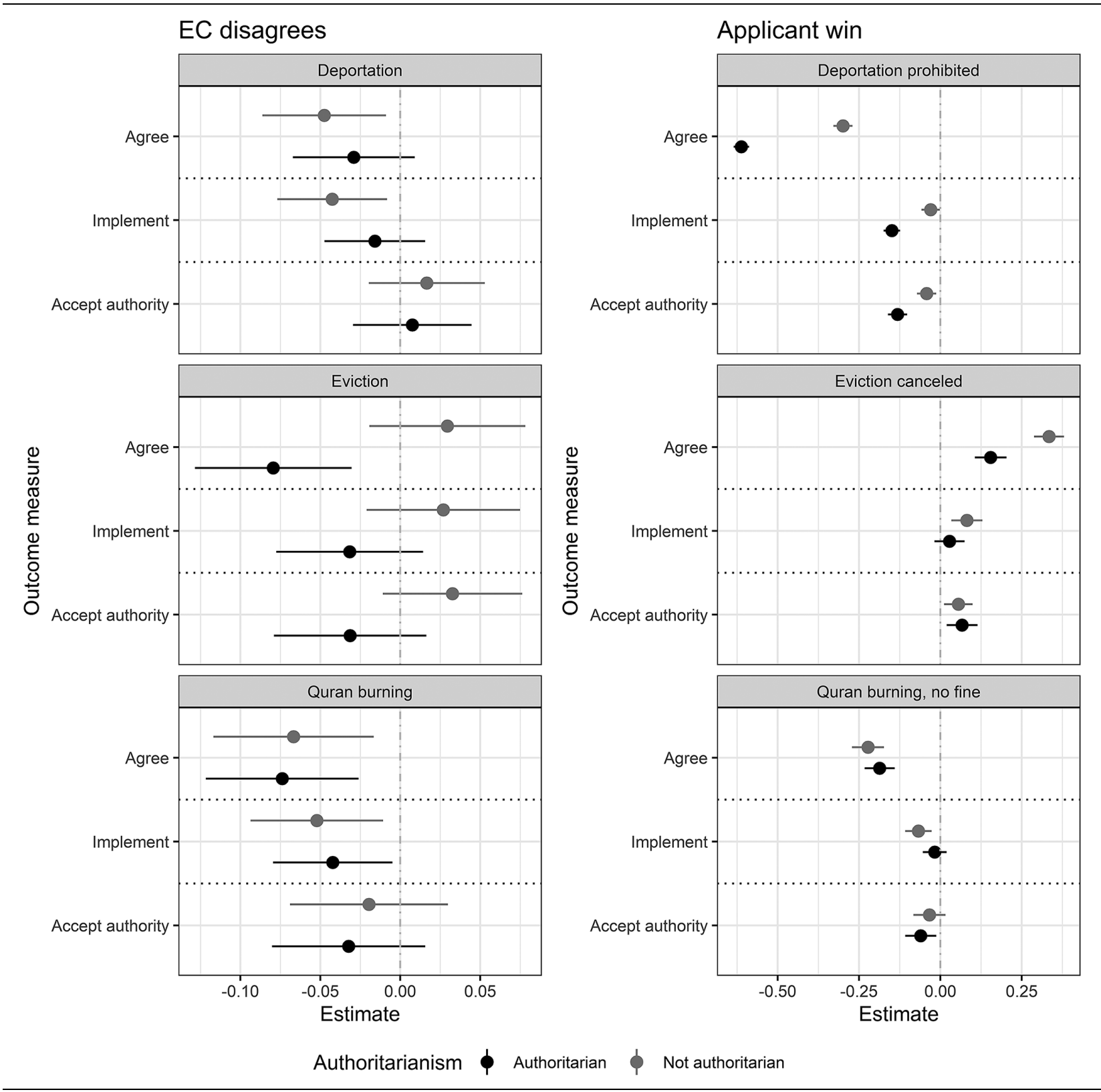

Note: Lines denote $95 \%$ confidence intervals.

\section{CONCLUSIONS}

Our central finding is that European respondents in five countries were not less acceptant of human rights judgments that came about through an international court overruling a national court, other than a small effect in Denmark and the United Kingdom. By contrast, support for implementation and even European court authority were significantly lower if an unsympathetic applicant won a case or a sympathetic applicant lost. Moreover, this is equally, and sometimes more, true for the most strident opponents of European courts: nationalists, authoritarians, Eurosceptics, and those who vote for right-wing populist parties. These findings suggest that public opposition to European human rights adjudication is more about the content of decisions than the location of authority and that it follows political preferences.

The question of whether people are inherently more acceptant of decisions that are made by national rather than international institutions is more broadly relevant to understanding the public backlash against international institutions. For example, international investment arbitration is facing strong public backlash in both developing and developed countries (Walter 2021). But we do not know the extent to which this discontent 
follows from the location of authority (international arbitral panels versus domestic courts) or findings favoring foreign multinational corporations (see Johns, Pelc, and Wellhausen 2019). Similarly, we could apply our experimental design to examine whether people are more acceptant of decisions by domestic war crimes tribunals rather than international ones. An alternative experimental design would be to directly examine public acceptance of a national or an international court striking down or upholding a government action rather than to examine disagreement between two judicial institutions at an international and a national level. ${ }^{24}$ Finally, we could take this experimental design outside the court context altogether, such as instances where the European Commission or another nonjudicial international body conflicts with a domestic agency. There is no guarantee that such experiments would yield the same findings.

There may well be substantive settings in which sovereignty concerns loom larger than the vignettes evaluated here. For example, the CJEU evaluates questions of national regulatory competence, which ascertain whether national legislation unjustly restricts EU market freedoms. Such judgments could well raise stronger sovereignty concerns than human rights cases as could matters involving national security. However, there are some reasons to believe that nationalist and authoritarian objections to international institutions may more generally follow the pattern found in this article. Other scholars have found that exclusive nationalism and its link to right-wing authoritarianism is more about cultural and ethnic in-group-out-group conflict than adherence to the territorial political unit of the state (Bar-On 2018; Dunn 2015). We might expect, then, that nationalist opposition to globalization is more about its content, especially rising immigration, rather than the relocation of authority to the international level.

These findings also have implications for efforts at mitigating public backlash. Liberal international institutions, and courts adjudicating human rights in particular, are ill suited to producing outcomes that are favored by nationalists and authoritarians. Human rights courts are designed to protect vulnerable, and sometimes unpopular, minorities from majority repression. Moreover, courts are supposed to build on legal precedent, produce case law that generates legal certainty, and display independence from popular and political pressures. Although we know that courts are sometimes responsive to public opinion, courts ultimately cannot fulfill their core functions if they are too sensitive to what is popular and what is not. Processbased responses to backlash, such as emphasizing a margin of appreciation or subsidiarity doctrine in the ECtHR context, are easier to implement that substance-based responses. Yet, increased deference also results in a denial of legitimate human rights claims and, as our results imply, will not by itself sustain public legitimacy. The dilemma faced by international human

\footnotetext{
${ }^{24}$ We thank a reviewer for this suggestion.
}

rights courts is thus more complex than a choice between self-restraint and backlash.

\section{SUPPLEMENTARY MATERIALS}

To view supplementary material for this article, please visit http://doi.org/10.1017/S0003055421001143.

\section{DATA AVAILABILITY STATEMENT}

Research documentation and data that support the findings of this study are openly available at the Amercian Political Science Review Dataverse: https://doi. org/10.7910/DVN/WJQITU.

\section{ACKNOWLEDGMENTS}

We thankfully acknowledge useful comments on the pre-registration from participants at the iCourts Power of International Courts conference, in Copenhagen (May 20-21, 2019), the Law and Society Annual Meeting (Washington DC), the 2019 American Political Science Association annual meeting (Washington DC), a seminar at the European University Institute, and the GRIPES seminar. We thank Soetkin Verhaegen, Elias Dinas, Kenneth Scheve, Mike Tomz, Lola Avril, Pola Cebulak, and Aleksandra Sojka for useful comments and suggestions.

\section{FUNDING STATEMENT}

This research was funded by Danish National Research Foundation Grant no. DNRF105 and conducted under the auspices of iCourts, The Danish National Research Foundation's Centre of Excellence for International Courts.

\section{CONFLICT OF INTEREST}

The authors declare no ethical issues or conflicts of interest in this research.

\section{ETHICAL STANDARDS}

The authors declare that the human-subjects research in this article was reviewed and approved by Georgetown University on July 15, 2019, as STUDY00000475 (included in the Dataverse materials). The author affirms that this article adheres to the APSA's Principles and Guidance on Human Subject Research.

\section{REFERENCES}

Adorno, Theodor W., Else Frenkel-Brunswik, Daniel J. Levinson, and R. Nevitt Sanford. 1993. The Authoritarian Personality. New York: W. W. Norton Company.

Altemeyer, Bob. 1988. Enemies of Freedom: Understanding RightWing Authoritarianism. San Francisco, CA: Jossey-Bass. 
Anderson, Brilé, Thomas Bernauer, and Aya Kachi. 2019. "Does International Pooling of Authority Affect the Perceived Legitimacy of Global Governance?" The Review of International Organizations 14 (4): 661-83.

Ballard-Rosa, Cameron, Mashail Malik, Stephanie Rickard, and Kenneth Scheve. 2021. "The Economic Origins of Authoritarian Values: Evidence from Local Trade Shocks in the United Kingdom." Comparative Political Studies. https:// doi.org/10.1177\%2F00104140211024296.

Bar-On, Tamir. 2018. "The Radical Right and Nationalism.” In The Oxford Handbook of the Radical Right, ed. Jens Rydgren, 17-37. Oxford: Oxford University Press.

Becher, Michael, and Sylvain Brouard. 2019. "Executive Accountability beyond Outcomes: Experimental Evidence on Public Evaluations of Powerful Prime Ministers.” Institute for Advanced Study in Toulouse. Working Paper 19-98. https:// econpapers.repec.org/paper/tseiastwp/122915.htm.

Beiser-McGrath, Liam F., and Thomas Bernauer. 2019. "Commitment Failures Are Unlikely to Undermine Public Support for the Paris Agreement." Nature Climate Change 9 (3): 248-52.

Blauberger, Michael, Anita Heindlmaier, Dion Kramer, Dorte Sindbjerg Martinsen, Jessica Sampson Thierry, Angelika Schenk, and Benjamin Werner. 2018. "ECJ Judges Read the Morning Papers. Explaining the Turnaround of European Citizenship Jurisprudence." Journal of European Public Policy 25 (10): 1422-41.

Blauberger, Michael, and Dorte Sindbjerg Martinsen. 2020. "The Court of Justice in Times of Politicisation: 'Law as a Mask and Shield' Revisited." Journal of European Public Policy 27 (3): 382-99.

Broberg, Morten, and Niels Fenger. 2014. Preliminary References to the European Court of Justice. Oxford: Oxford University Press.

Caldeira, Gregory A., and James L. Gibson. 1995. "The Legitimacy of the Court of Justice in the European Union: Models of Institutional Support." The American Political Science Review 89 (2): 356-76.

Chaudoin, Stephen. 2014. "Promises or Policies? An Experimental Analysis of International Agreements and Audience Reactions." International Organization 68 (1): 235-56.

Christenson, Dino P., and Douglas L. Kriner. 2017. "Constitutional Qualms or Politics as Usual? The Factors Shaping Public Support for Unilateral Action." American Journal of Political Science 61 (2): 335-49.

Clark, Nicholas J., and Robert Rohrschneider. 2019. "The Relationship between National Identity and European Union Evaluations, 19932017." European Union Politics 20 (3): 384-405.

Colantone, Italo, and Piero Stanig. 2018. "Global Competition and Brexit." American Political Science Review 112 (2): 201-18.

Colantone, Italo, and Piero Stanig. 2019. "The Trade Origins of Economic Nationalism: Import Competition and Voting Behavior in Western Europe." American Journal of Political Science 62 (4): 936-53.

Copelovitch, Mark, and Jon C. W. Pevehouse. 2019. "International Organizations in a New Era of Populist Nationalism." The Review of International Organizations 14 (2): 169-86.

Craig, Paul, and Gráinne De Búrca. 2020. EU Law: Text, Cases, and Materials. Oxford: Oxford University Press.

Dederke, Julian. 2021. "CJEU Judgments in the News: Capturing the Public Salience of Decisions of the EU's Highest Court." Journal of European Public Policy, 1-20. https://doi.org/10.1080/ 13501763.2021.1872682.

Dellmuth, Lisa Maria, Jan Aart Scholte, and Jonas Tallberg. 2019. "Institutional Sources of Legitimacy for International Organisations: beyond Procedure versus Performance." Review of International Studies 45 (4): 627-46.

Dellmuth, Lisa Maria, and Jonas Tallberg. 2015. "The Social Legitimacy of International Organisations: Interest Representation, Institutional Performance, and Confidence Extrapolation in the United Nations." Review of International Studies 41 (3): 451-75.

de Vreese, Claes H., and Hajo G. Boomgaarden. 2005. "Projecting EU Referendums: Fear of Immigration and Support for European Integration.” European Union Politics 6 (1): 59-82.

de Vries, Catherine E. 2018. Euroscepticism and the Future of European Integration. Oxford: Oxford University Press.
Dinas, Elias, and Ezequiel Gonzalez-Ocantos. 2021. "Defending the European Court of Human Rights: Experimental Evidence from Britain.” European Journal of Political Research 60 (2) 397-417.

Dunn, Kris. 2015. "Preference for Radical Right-Wing Populist Parties among Exclusive-Nationalists and Authoritarians." Party Politics 21 (3): 367-80.

Dunwoody, Philip T., and Friedrich Funke. 2016. "The AggressionSubmission-Conventionalism Scale: Testing a New Three Factor Measure of Authoritarianism," Journal of Social and Political Psychology 4 (2): 571-600.

Dunwoody, Philip T., and Sam G. McFarland. 2018. "Support for Anti-Muslim Policies: The Role of Political Traits and Threat Perception." Political Psychology 39 (1): 89-106.

Ecker-Ehrhardt, Matthias. 2014. "Why Parties Politicise International Institutions: On Globalisation Backlash and Authority Contestation." Review of International Political Economy 21 (6): 1275-312.

Esaiasson, Peter, Mikael Persson, Mikael Gilljam, and Torun Lindholm. 2019. "Reconsidering the Role of Procedures for Decision Acceptance." British Journal of Political Science 49 (1): 291-314.

Feldman, Stanley, and Karen Stenner. 1997. "Perceived Threat and Authoritarianism." Political Psychology 18 (4): 741-70.

Fligstein, Neil, Alina Polyakova, and Wayne Sandholtz. 2012. "European Integration, Nationalism and European Identity." JCMS: Journal of Common Market Studies 50 (s1): 106-22.

Flogaitis, Spyridon, Tom Zwart, and Julie Fraser. 2013. The European Court of Human Rights and Its Discontents: Turning Criticism into Strength. Northampton, MA: Edward Elgar.

Follesdal, Andreas. 1998. "Survey Article: Subsidiarity." Journal of Political Philosophy 6 (2): 190-218.

Follesdal, Andreas. 2020. "Survey Article: The Legitimacy of International Courts." Journal of Political Philosophy 28 (4): 476-99.

Gibson, James L., and Gregory A. Caldeira. 1998. "Changes in the Legitimacy of the European Court of Justice: A Post-Maastricht Analysis." British Journal of Political Science 28 (1): 63-91.

Gibson, James L., Gregory A. Caldeira, and Vanessa A. Baird. 1998. "On the Legitimacy of National High Courts." American Political Science Review 92 (2): 343-58.

Gill-Pedro, Eduardo. 2019. EU Law, Fundamental Rights and National Democracy. London: Routledge.

Gonzalez-Ocantos, Ezequiel, and Elias Dinas. 2019. "Compensation and Compliance: Sources of Public Acceptance of the U.K. Supreme Court's Brexit Decision." Law \& Society Review 53 (3): 889-919.

Graham, Matthew H., and Milan W. Svolik. 2020. "Democracy in America? Partisanship, Polarization, and the Robustness of Support for Democracy in the United States." American Political Science Review 114 (2): 392-409.

Hafner-Burton, Emilie M., Edward D. Mansfield, and Jon C. W. Pevehouse. 2015. "Human Rights Institutions, Sovereignty Costs and Democratization." British Journal of Political Science 45 (1): 1-27.

Hatzopoulos, Vassilis. 2014. "Turkish Service Recipients under the EU-Turkey Association Agreement: Demirkan; Case C-221/11, Leyla Ecem Demirkan v. Bundesrepublik Deutschland Case Law: Section A: Court of Justice." Common Market Law Review 51 (2): 647-64.

Helfer, Laurence. 2018. "Populism and International Human Rights Institutions: A Survival Guide.” SSRN Working Paper 3202633. https://papers.ssrn.com/abstract=3202633.

Herrmann, Richard K., Pierangelo Isernia, and Paolo Segatti. 2009. "Attachment to the Nation and International Relations: Dimensions of Identity and Their Relationship to War and Peace." Political Psychology 30 (5): 721-54.

Hirschl, Ran. 2008. "The Judicialization of Mega-Politics and the Rise of Political Courts." Annual Review of Political Science 11: 93-118.

Hobolt, Sara B. 2016. "The Brexit Vote: A Divided Nation, a Divided Continent." Journal of European Public Policy 23 (9): 1259-77.

Hobolt, Sara B., and Catherine E. de Vries. 2016. "Public Support for European Integration.” Annual Review of Political Science 19: 413-32.

Hofmann, Andreas. 2018. "Resistance against the Court of Justice of the European Union." International Journal of Law in Context 14 (2): 258-74. 
Hooghe, Liesbet, and Gary Marks. 2004. "Does Identity or Economic Rationality Drive Public Opinion on European Integration?" $P S$ : Political Science \& Politics 37 (3): 415-20.

Hooghe, Liesbet, and Gary Marks. 2005. "Calculation, Community and Cues: Public Opinion on European Integration.” European Union Politics 6 (4): 419-43.

Hooghe, Liesbet, and Gary Marks. 2009. "A Postfunctionalist Theory of European Integration: From Permissive Consensus to Constraining Dissensus." British Journal of Political Science 39 (1): 1-23. http://doi.org/10.1017/S0007123408000409.

Hooghe, Liesbet, and Gary Marks. 2018. "Cleavage Theory Meets Europe's Crises: Lipset, Rokkan, and the Transnational Cleavage." Journal of European Public Policy 25 (1): 109-35.

Höpner, Martin, and Armin Schäfer. 2012. "Embeddedness and Regional Integration: Waiting for Polanyi in a Hayekian Setting." International Organization 66 (3): 429-55.

Hough, Andrew. 2011. "Prisoner Vote: What MPs Said in Heated Debate." Telegraph, February 11. http://www.telegraph.co.uk/ news/politics/8317485/Prisoner-vote-what-MPs-said-in-heateddebate.html.

Jensen, J. Bradford, Dennis P. Quinn, and Stephen Weymouth. 2017. "Winners and Losers in International Trade: The Effects on US Presidential Voting." International Organization 71 (3): 423-57.

Johns, Leslie, Krzysztof J. Pelc, and Rachel L. Wellhausen. 2019. "How a Retreat from Global Economic Governance May Empower Business Interests." Journal of Politics 81 (2): 731-38.

Lamour, Christian, and Renáta Varga. 2020. "The Border as a Resource in Right-Wing Populist Discourse: Viktor Orbán and the Diasporas in a Multi-Scalar Europe." Journal of Borderlands Studies 35 (3): 335-50.

Lampert, Thomas F. 2017. "Prioritizing National Security at the Expense of Refugee Rights: The Effects of HT v. Land BadenWurttenberg." Boston College International \& Comparative Law Review 14. https://lawdigitalcommons.bc.edu/iclr/vol40/iss3/2.

Madsen, Mikael Rask. 2018. "Between Supremacy of Parliament and Erga Omnes Effects: The Bindingness of the European Convention in Danish Law." In Binding Effect of Judicial Decisions - National and International Perspectives, eds. Pavel Samal, Guido Raimondi, and Koen Lenaerts, 193-210. Alphen: Kluwer Law International.

Madsen, Mikael Rask. 2020. "Two Level Politics and Backlash against International Courts: Evidence from the Politicisation of the European Court of Human Rights." The British Journal of Politics and International Relations 22 (4): 728-38.

Madsen, Mikael Rask, Juan A. Mayoral, Anton Strezhnev, and Erik Voeten. 2021. "Replication Data for: Sovereignty, Substance, and Public Support for European Courts' Human Rights Rulings." Harvard Dataverse. Dataset. https://doi.org/10.7910/DVN/ WJOITU.

Madsen, Mikael Rask, Pola Cebulak, and Micha Wiebusch. 2018. "Backlash against International Courts: Explaining the Forms and Patterns of Resistance to International Courts." International Journal of Law in Context 14 (2): 197-220.

McLaren, Lauren, M. 2005. Identity, Interests and Attitudes to European Integration. Vienna, Austria: Springer.

Miratrix, Luke W., Jasjeet S. Sekhon, and Bin Yu. 2013. “Adjusting Treatment Effect Estimates by Post-Stratification in Randomized Experiments." Journal of the Royal Statistical Society: Series B (Statistical Methodology) 75 (2): 369-96.

Mohay, Ágoston, and Norbert Tóth. 2017. "Decision 22/2016. (XII. 5.) $\mathrm{AB}$ on the Interpretation of Article E)(2) of the Fundamental Law." The American Journal of International Law 111 (2): 468-75.

Moravcsik, Andrew. 2000. "The Origins of Human Rights Regimes: Democratic Delegation in Postwar Europe." International Organization 54 (2): 217-52.

Mudde, Cas. 2004. "The Populist Zeitgeist." Government and Opposition 39 (4): 542-63.

Mutz, Diana C. 2018. "Status Threat, Not Economic Hardship, Explains the 2016 Presidential Vote." Proceedings of the National Academy of Sciences 115 (19): E4330-39.

Norris, Pippa, and Ronald, Inglehart. 2019. Cultural Backlash: Trump, Brexit, and Authoritarian Populism. New York: Cambridge University Press.
Pollack, Mark A. 2017. "The Legitimacy of the Court of Justice of the European Union.” SSRN Working Paper 2911836. https:// doi.org/10.2139/ssrn.2911836.

Popelier, Patricia, Sarah Lambrecht, and Koen Lemmens, eds. 2016. Criticism of the European Court of Human Rights: Shifting the Convention System: Counter-Dynamics at the National and EU Level. Cambridge: Intersentia.

Reeves, Andrew, and Jon C. Rogowski. 2018. "The Public Cost of Unilateral Action." American Journal of Political Science 62 (2): 424-40.

Rohrschneider, Robert. 2002. "The Democracy Deficit and Mass Support for an EU-Wide Government." American Journal of Political Science 46 (2): 463-75.

Rooduijn, Matthijs, Stijn van Kessel, Caterina Froio, Andrea Pirro, Sarah De Lange, Daphne Halikiopoulou, Paul Lewis, Cas Mudde, and Paul Taggart. 2019. The PopuList: An Overview of Populist, Far Right, Far Left and Eurosceptic Parties in Europe [computer file]. https://popu-list.org.

Sandholtz, Wayne, Yining Bei, and Kayla Caldwell. 2017. "Backlash and International Human Rights Courts." Paper prepared for the Contracting Human Rights Workshop at the University of California, Santa Barbara.

Scharpf, Fritz. 1998. "Negative and Positive Integration in the Political Economy of European Welfare States." In The Future of European Welfare: A New Social Contract? eds. Martin Rhodes and Yves Mény, 157-77. London: Palgrave Macmillan.

Sides, John, and Jack Citrin. 2007. "European Opinion about Immigration: The Role of Identities, Interests and Information." British Journal of Political Science 37 (3): 477-504.

Smet, Stijn. 2019. "Free Speech versus Religious Feelings, the Sequel: Defamation of the Prophet Muhammad in E.S. v Austria." European Constitutional Law Review 15 (1): 158-70.

Spano, Robert. 2014. "Universality or Diversity of Human Rights? Strasbourg in the Age of Subsidiarity." Human Rights Law Review 14 (3): 487-502.

Spano, Robert. 2018. "The Future of the European Court of Human Rights-Subsidiarity, Process-Based Review and the Rule of Law." Human Rights Law Review 18 (3): 473-94.

Stenner, Karen. 2005. The Authoritarian Dynamic. Cambridge: Cambridge University Press.

Stiansen, Øyvind, and Erik Voeten. 2020. "Backlash and Judicial Restraint: Evidence from the European Court of Human Rights." International Studies Quarterly 64 (4): 770-84.

Tallberg, Jonas, and Michael Zürn. 2019. "The Legitimacy and Legitimation of International Organizations: Introduction and Framework." The Review of International Organizations 14: 581-606.

Turnbull-Dugarte, Stuart J., and Daniel Devine. 2021. "Can EU Judicial Intervention Increase Polity Scepticism? QuasiExperimental Evidence from Spain." Journal of European Public Policy, 1-26. https://doi.org/10.1080/13501763.2021.1901963.

Tyler, Tom R. 2006. Why People Obey the Law. Princeton, NJ: Princeton University Press.

Tyler, Tom R., and Kenneth Rasinski. 1991. "Procedural Justice, Institutional Legitimacy, and the Acceptance of Unpopular U.S. Supreme Court Decisions: A Reply to Gibson." Law \& Society Review 25 (3): 621-30.

Walter, Stefanie. 2021. "The Backlash against Globalization." Annual Review of Political Science 24: 421-42.

Werner, Hannah, and Sofie Marien. 2020. "Process vs. Outcome? How to Evaluate the Effects of Participatory Processes on Legitimacy Perceptions.” British Journal of Political Science, 1-8. https://doi.org/10.1017/S0007123420000459.

Wright, Matthew, Jack Citrin, and Jonathan Wand. 2012 "Alternative Measures of American National Identity: Implications for the Civic-Ethnic Distinction." Political Psychology 33 (4): 469-82.

Zvobgo, Kelebogile. 2019. "Human Rights versus National Interests: Shifting US Public Attitudes on the International Criminal Court." International Studies Quarterly 63 (4): 1065-78.

Zvobgo, Kelebogile, and Stephen Chaudoin. 2021. "Complementarity and Public Views on Overlapping Domestic and International Courts." Unpublished Manuscript. http:// www.stephenchaudoin.com/complementarity.pdf. 